\title{
EFEITOS DO PERIODO DE COMPETIÇÃO DAS PLANTAS DANINHAS SOBRE A PRODUTIVIDADE DO AMENDOIM (Arachis hypogaea L.) E O TEOR DE MACRONUTRIENTES EM SUAS SEMENTES
}

ROBINSON ANTONIO PITELLI

Orientador: EDUARDO CASTANHO FERRAZ

Dissertação apresentada à Escola Superior de Agricultura "Luiz de Queiroz", da Universidade de São Paulo, para obtenção do titulo de Mestre em Solos e Nutrição de Plantas.

PIRACICABA

Estado de São Paulo - Brasil

Fevereiro - 1980 


\section{Aos meus pais, CAETANO \\ e MARIA AMÁLIA,}

\section{OFEREÇO}

A MARIA ANGELICA, minha esposa, ROBINSON LUIZ e ANGELICA MARIA, meus filhos, 
$\underline{A} \underline{G} \underline{R} \underline{A} \underline{\mathrm{E}} \underline{\mathrm{C}} \underline{\mathrm{M}} \underline{\mathrm{E}} \underline{\mathrm{N}} \underline{\mathrm{T}} \underline{O} \underline{\mathrm{S}}$

Agradeço a'todos que, direta ou indiretamente, contribuiram na execução deste trabalho, e especialmente:

- Ao Professor Dr. Eduardo Castanho Ferraz, pe la orientação, amizade e atenção a nós dedicada na condução da presiente Dissertação.

- Aos colegas Dr. Giorgio De Marinis, Dr. Pau lo Roberto Camargo de Castro; Dr. Ricardo Victória Filho, Dr. Dilermando Perecin, Dr. Rubens Sader e Engo Agro Silvano Bian co, pelas sugestões e manifestações de apoio.

- Aos Drs. Henrique Paulo Haag, Renato Sarruge e MS Gilberto Diniz de Oliveira, pelas facilidades oferecidas para as anälises químicas das sementes.

- A todos os professores e funcionārios do De partamento de Biologia Aplicada à Agropecuária, pela amizade e facilidades oferecidas.

- A Faculdade de Ciências Agrárias e Veteriná rias de Jaboticabal e à Escola Superior de Agricultura "Luiz de Queiroz", pela nossa formação universitäria.

- Aos auxiliares de laboratório Francisco Ri gler Neto e Sidney de Campos, pela inestimável ajuda e pela dedicação ímpar demonstrada na condução desta pesquisa.

- A Maria de Lourdes Moretto, pelos serviços de datilografia e amizade.

- A minha esposa, Maria Angélica, pela dedica ção, incentivo e confiança. 


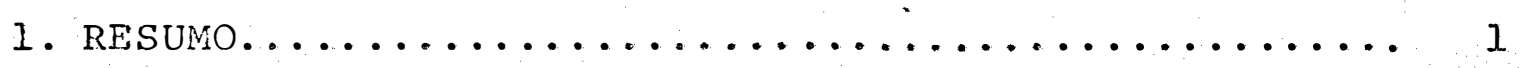

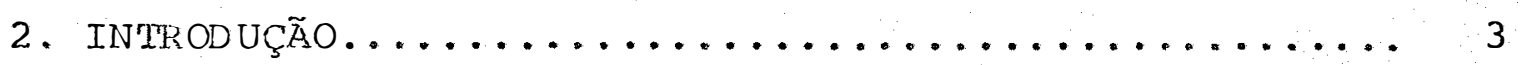

3. REVISÃO DE IITERATURA...................... 5

4. MATERTAL E METODOS...................... 20

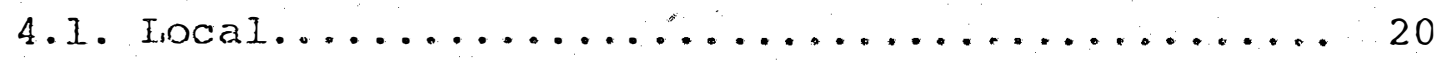

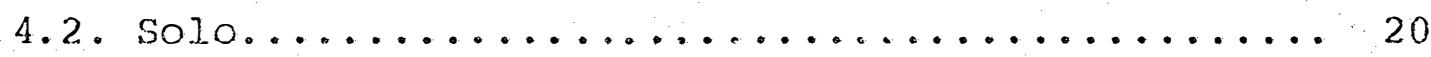

4.3. Preparo do solo....................... 21

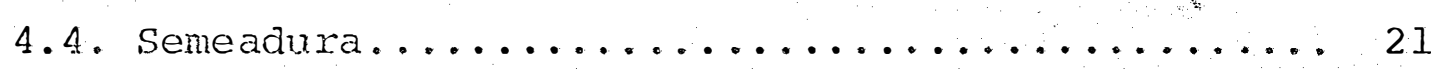

4.5. Iratamentos......................... 22

4.6. Delineamento experimental............. 23

4.7. Tratamento fitossanitärio.............. 23

4.8. Observações sobre a comunidade infestante..... 23

4.9. Observações sobre a produção da cultura do amer

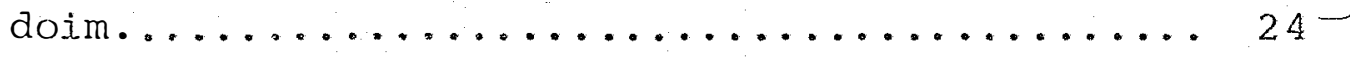

4.10. Parâmetros climatolögicos............... 25

4.11. Anälise química das sementes............. 25

4.12. Tratamento estatístico dos dados.......... 26

5. RESUITADOS E DISCUSST̃O ................... 33

6. CONCLUSÕES................................. 79

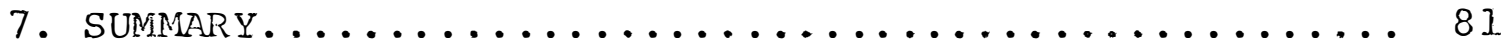

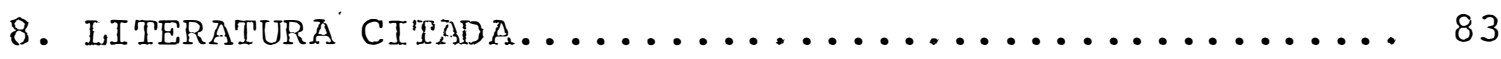


TABEIA

pàginà

1 - Pesos médios da matéria seca acumulada pela comu nidade infestante ern $0,32 \mathrm{~m}^{2}$ da ärea ūtil cias parcelas experimentais. Média. de 3 repetições. 38

2 - Efeitos do período de competi.ção de plantas danj. nhas sobre as produções de vagens e de sementes por parcela de $5,4 \mathrm{~m}^{2}$ e porcentagem de casca em amendoim, cultivar 'Tatú-53'. Médjas de 3 repe

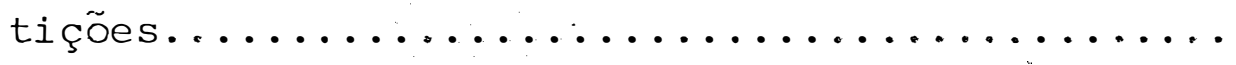
)

3 - Coeficientes de correlação e equações de regres são inear entre a extensão do período de compe tição, expressos em dias a partir da emergência da cultura, e o peso da produção de vagens de

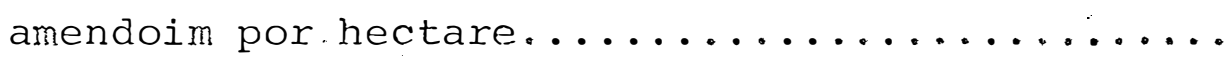

$4^{*}$ - Coeficientes de correlação e equações de regres são linear entre a extensão do periodo de contro le das plantas daninhas a partir da germinação da cultura e o peso da produção de vagens de amen

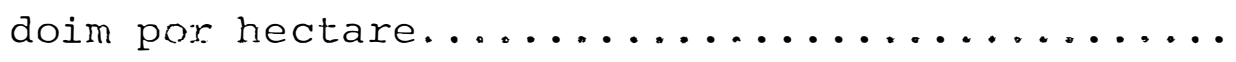

5 - Ereitos co tempo de competição das plantas dani nhas sobre o nümero de plantas de amendoin por parcela $e$ peso das produções de vagens e de se mentes por planta. Média de 3 repetiçöes......

6 - Efeitos do perīodo de competição das plantas da ninhas sobre o nümero médio de sementes por va gèm, nümero médio de vagens por̀ planta e peso mé dio de 100 sementes de amendoim. Média de 3 re

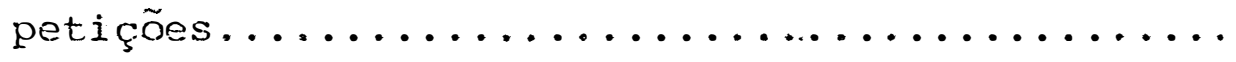


7 - Efeitos do pexíodo de competição das plantas da ninhas sobre a distribuição porcentuai do tama nho de vagens de amendoim. Média de 3 repetí

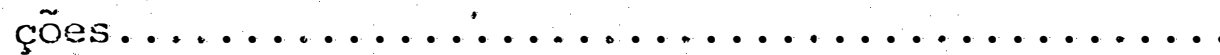

8 - Efeitos do tempo de competição das plantas dani nhas sobre distribuição porcentual dos diâmetros - médios de sementes de amendoim. Média de 3 repe

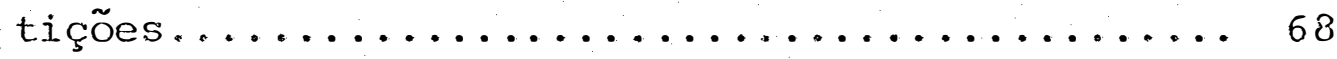

9 - Efeitos do período de competição das plantas dạ ninhas sobre os teores de nitrogênio, fösforo, po tāssio, cálcio e magnésio em sementes de amen

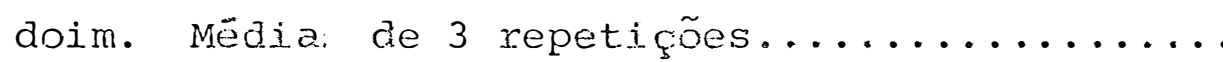

10 - Efeitos do período de competição das plantas da ninhas sobre o acümulo äe nitrogênio, fösforo, potássio, cálcio e magnésio em sementes de amen

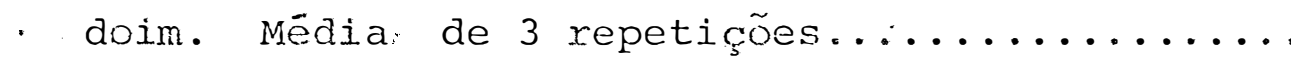




\section{LISTA DE FIGURAS}

FIGURA

Pāgina

1 - Amplitudes das varíações térmicas (linhas verti cais), temperaturas médias diārias (linha contí nua) e precipitações diārias (barras verticais) ocorridas no mês de outubro de 1976 na FCAV/ UNESP, Jaboticabal. Temperatura média mensal de $22,0^{\circ} \mathrm{C}$ e precipitação total do mês $149,3 \mathrm{~mm} \ldots . .28$

2 - Amplitudes das variações térmicas (linhas verti cais), temperaturas médias aíárias (linha contí nua) e precipitaçọes diárias (barras verticais) ocorridas no mês de novembro de 1976 na FCAV/ UNESP, Jaboticabal. Temperatura mëdia mensa i de $23,3^{\circ} \mathrm{C} \in$ precipj.táção total do mês $140,7 \mathrm{~mm} \ldots . .29$

3 - Amplitudes das variações térmicas (linhas verti cais), temperaturas médias diārias (linha contí nua) e precipitações diárias (barras verticais) ocorridas no mês de dezembro de 1.976 na FCAV/ UNESP, Jaboticabal. Temperatura média mensal de $24,0^{\circ} \mathrm{C}$ e precipitação total do mês $217,3 \mathrm{~mm} \ldots . .30$

4 - Amplitudes das variações térmicas (linhas verti cais), temperaturas médias diārias (linha contí nua) e precipitações diärias (barras verticais) ocorridas no més de janeiro de 1977 na FCAV/ UNESP, Jaboticabal. Temperatura média mensal de $23,8^{\circ} \mathrm{C}$ e precipitação total do mês $312,4 \mathrm{~mm}$.... 31 
5 - Amplitudes das variações tērmicas (linhas verti cais), temperaturas mēdias diärias (linha contí nual e precipitações diārias (barras verticais) ocorridas no mês de fevereiro de 1977 na FCAV/ UNESP, Jaboticabal. Temperatura mēdia mensal de $25,0^{\circ} \mathrm{C}$ e precipitação total do mês $76,2 \mathrm{~mm} \ldots . . .32$

6 - Coeficientes angulares das regressões lineares e médias nos intervalos de tratamentos com diferen tes períodos no mato, referentes aos parâmetros de porcentagem de casca e peso das produções de

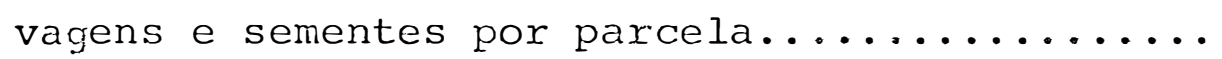

7 - Coeficientes angulares das regressões lineares e médias nos intervalos de tratamentos com diferen tes períodos no mato, referentes aos paxâmetros de "stand" da cultura e pesos das produções de

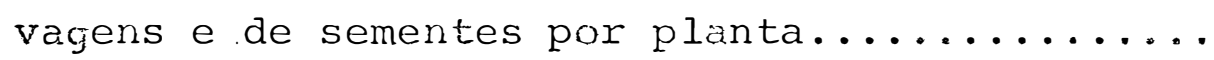


Com o objetivo de estudar os efeitos de dife rentes periodos de competição das plantas daninhas sobre al guns parâmetros produtivos da cultura do amendoinzejro cv. 'ratú-53', foi instalada e conduzida a presente pesquisa, em Jaboticabal, em solo Latossol. Vermelho Escuro - Ease arenosa. o delineamento experimental utilizado foi o de blocos casualizados, sendo os tratamentos djvididos basicamen te em dois grupos: no primeiro a cultura foi mantida no mato desde a germinação atë deteminada Ease de seu ciclo de desen volvimento e, no secundo a cultura foi conservada livre da competição por períodos equivalentes ao primeiro grupo, após o qual o mato foi deixado crescex livremente. As extensões dos períodos estudados foram $0,10,20,30,40,50,60,70,80$, 90 e 100 dias.

Basicamente, a competição alterou a distribui ção porcentual do tamanho das sementes, aumentando a partici pação das sementes pequenas e, conseqụentemente, diminuindo a 
das sementes grandes. Desta maneira, o peso médio de 100 se mentes foi reduzido. Este fato e o decrëscimo do número de vagens por planta foram os principais responsáveis pela redu ção da produção de sementes por planta, jã que o nūmero médio de sementes por vagem não foi influenciado pela competição. Sendo que o "stand" da cultura e a porcentagem de casca do amendoim não foram afetados pela competição, a redução da prọ dução de sementes por planta foi o principal fator determinan te do decréscimo da produtividade de vagens da cultura provo dada pela' competição. os efeitos do mato foram mais intensos sobxe os teores de cálcio e fósforo das sementes, enquanto que o nitrogênio, potássio e magnësio foram apenas levemente in fluenciados pela competição.

Nas condições em que foi desenvolvido o expexi mento, o amendoim mostrou-se relativamente tolerante à compe tição, de maneira que um período de 10 dias livre das plantas daninhas no início de seu ciclo de desenvolvimento proporcio nou-The condições plenas de produtividade, comparada à teste munha no limpo. Por outro lado, quando foì permitido que o mato desenvolvesse desde o início do ciclo de cultura, o pe ríodo acima do qual a competição alterou a produtividade de cultura foi igual ou superior a 50 dias. 


\section{INTRODUÇत̃O}

O amendoim (Arachis hypogaea I..), leguminosa originária da fimérica do Sul, apesar de ser plantada desde tempos imemoriais pelos jndigenas aesta região, somente nos ültimos decênios recebeu a atenção que faz juz, passanaio de cultura subsidiäria parà a principal em värias regiões, onde atualmente representa importante atividade econômica e fator de desenvolvimento regional. E considerada, em importância, a segunda leguminosa do murido, com ampla gana de utilizações econômicas.

Entretanto a produção de amendoim, concentrada principalmente nos Estados de São Paulo e Parană, nos ültjumos anos vem sofrendo decréscimos sucessivos. Tal fato, segundo especialjstas, se deve especialmente à baixa rentabilidade da cultura, em relação às demais. Como a rentabilidade é uma ex pressão econônica do balanço entre gastos e receita, todo e qualquer Eatox que incremente os gastos e, tambēm, minimize a receita, assume singular importância nos destinos da cultura 
como empresa rentável. Estes fatores são muitos, podendo-se destacar a ocorrência das plantas daninhas, como um dos prin cipais, pois além de diminuir as receitas através de altera ções negativas na qualidade e quantídade da produção, aumen tani os gastoś envolvendo insumos, equipamentos e mão-de-obra.

Os métodos tradicionais de controle como capi nas e cultivo mecầnico, causam sêrios problemas para a cultú ra do amendoinn. Além de suas aplicações serem restritas ao período anterior à emissão do ginóforo, a amontoa de terra e de material orgânico próximo à linha de semeadura, aumenta as possibilidades de problemas com a Nurcha do selerotium. Na utilização de mëtodos quimicos de controle de plantas daní nhas, o conhecimento da época, e duração deste çontrole é de singulax importância na determinação não só da eficiência do controle como támbém no próprio balanço receita-custo.

Assim sendo, no presente trabaiho procurou - se estudar os efeitos de diferentes ëpocas e diferentes exten sões de períodos de competição das plantas daninhas sobre pa râmetros qualitativos e quantitativos da produção da cuitura do amendoim visando fornecer as primejtas informações, no Brạ sil, para uma aplicação sistemätica de produtos herbididas em pré e pós-emergência nestá cultura. Adicionalmente, estudouse os efeitos desta competição sobre os tèores de nitrogênio, fósforo, potāssicio, calcio e magnésio das sementes. 
3. REVISÃO DE LITERATURA

A competição entre a espécie cultivada numa de terminada área e a comunidade infestante foi esquematizada por BLEASDALE (1960) e o esquema modificado por BLANCO (1972). Segundo este esquema, o grau de competiçăo depende da inter venção de fatores ligados tanto à comunidade infestante (com posição específica, densidade e distribuição das plantas dani nhas), como à própria cultura (gênero, espécie ou cultivar, es paçanento entre sulcos e densidade de semeadura). Além disso, depende também da época e dusäção do tempo em que permanecem juntas a cultura e a comunidade infestante e é modificado pe las condições edáficas, climäticas e tratos culturais. Todos esses fatores, teoricamente, são passiveis de controle. Entre tanto, na prática, apenas o tempo e época de convivência múl tipla têm sido controlados.

$\mathrm{Na}$ cultura do amendoim foi verificado que de terminadas cultivares de porte ereto, 'Valência', por exem plo, são mais tolerantes à competição das plantas daninhas 
que cultivares prostradas, como por exemplo 'Malawi Djxie Run ner' (FEAKIN, 1973).

O espaçamento entre sulcoś de semeadura tem grande importância na determinação do grau de competição en tre plantas daninhas e a cultura do amendoim. FEAKIN (1973) observa que a parte aérea do amendoinzeiro tem um desenvolvi mento inicial relativamente lento, de modo que, a cobertura eficiente do solo ocorre apenas 8-12 semanas apōs a emergência da cultura. HAUSER et alii (1975) observaram que, em espaçamen to de aproximadamente $0,40 \mathrm{~m}$ entre suicos de semeadura, o som breamento efetivo do solo ocorre com 2 - 4 semanas de antece dência em relação a um espaçamento em torno de 0,80 m. Então, um espaçamento menor propiciaria uma maior competitiviảade à cultura, aumentando a eficiência das medidas de controle, con forme foi observado por HAMMERTON (1974).

As diferentes espēcies daninhas que se desen volverem na mesma ärea da cultura influenciarão, em parte, o grau de competição, pois as habilidades competitivas variam com a espēcie vegetal. Supõe-se que quanto mais semelhantes fisiologicamente são duas espécies, e, muitas vezes, isto es tà relacionado à classificação taxionômica (CLARKE, 1971), maís prōximas serão suas necessidades e maís intensa serā a competição pelos fatores limitados no ecossistema comum. HOLM et alii (1977) afirmam que Portulaca oleracea L. é uma planta bastante competitiva com o amendoim, devido a semelhan ça do hābito de crescimento de ambas.

BLANCO (1972) ressalta.que em elevadas infesta 
ções de plantas daninhas, a importância de cada espécie como elemento competitivo, fica diminuída. Sob este aspecto, YORK e COBLE (1977), estudando a competição entre várias densida des de Panicum dichotomiflorum Michs, e a cultura do amendoim, verificam que, em infestações naturais; as populações desta espécie eram de quinze vezes mais numerosas em relação maior densidade estudada, no entanto o peso de matéria seca era apenas 1,5 vezes mais elevada. Isto indica que a competi ção interespecífica, imposta pelo restante da comunidade, di minuiu o potencial de crescimento e, dentro de certos limites, o potencial de competição da gramínea.

Outro aspecto importante a ser observado com relação às espécies infestantes presentes, é qụe os herbicí das seletivos, normalmente são inôcuos às espécies fisiologi camente próximas àquelas cultivadas, que teoricamente são as mais competitivas. Com isso é possível a seleção de uma flo ra bastante competitiva em relação à cultura e, ao mesmo tem po, fortalecida pela eliminação de parte da competição inte respecífica. Este fenômeno é bastante flagrante em locais on de ocorre o cultivo intensivo de apenas uma espécie comercial durante anos sucessivos. A rotação de culturas contorna este problema de maneira bastante satisfatória.

Existem alguns problemas específicos com deter minadas espécies, como é o caso observado com Desmodium tox tuosum (Sw.) DC. e Cassia •btusifolia L., as duas espécies da ninhas mais problemáticas para a cultura do amendoim nos está dos de Alabama, Georgia e Flórida dos Estados Unidos da Améri 
ca do Norte (BUCHANAM et a $z_{i} i$, 1976). Estas duas espécies não são citadas por BLANCO (1978) como infestantes de culturas no Brasil. Estas espécies também pertencem à família Legumino sae e, quando jovens, apresentam folhagem bastante parecida à do amendoim. Quando germinam próximas aos sulcos de semeadu ra, não são notadas durante as capinas manuais e apenas tor nam-se evidentes quando, devido ao maior porte, se destacam so bre a folhagem da cultura, ocasião em que já prejudicaram as plantas de amendoim próximas (HAUSER et alii, 1975).

HOLM et alii (1977) afirmam que, no panorama mundial, até o presente momento representantes das famílias Gramineae e Cyperaceae são os maiores problemas para a cultu ra do amendoim. Das oito espécies daninhas que os aucores consideram como sérios problemas para esta cultura, sete per tencem à família Gramineae: Cynodon dactylon (I.) Pers., Echinochloa crusgalli (L.) Beauv., Echinochloa colonum (L.) Link., Eleusine indica (L.) Gaertn., Imperata cylindrica (L.) Beauv., Digitaria sanguinalis (L.) Scop., Rottboellia exalta ta L.. Apenas uma Dicotiledoneae: Ageratum conyzoides L. (Compositae).

No Brasil, dentre as plantas daninhas mais co mumente encontradas em experimentos com amendoim, destacam-se: Digitaria sanguinalis (LEIDERMAN et alii, 1963; LEIDERMAN e SANTOS, 1964; FORSTER, 1968; LEIDERMAN e SANTOS, 1968; FORS TER e DEUHBER, 1970; GRASSI et a $i$ i , 1970; GRASSI et a $i$ i, 1973; GRASSI e LEIDERMAN, 1974; LEVI, 1975; SADER, 1975; VIC TORIA Fo et alii, 1976; PACHECO, 1977 e BIANCO, 1978), Cen 
chrus echinatus L. (FORSTER, 1968; LEIDERMAN e SANTOS, 1968; SAN'TOS et alii, 1967; FORSTER e DEUBER, 1970; GRASSI et alii, 1970; GRASSI e LEIDERMAN, 1974; LEVI, 1975; SADER, 1975; VIC TÓRIA Fo et alii, 1976 e BIANCO, 1978). Bidens pilosa L . (LEIDERMAN et alii, 1963; FORSTER, 1968; GRASSI et alii, 1970; CAMARGO, 1974; LEIDERMAN et alii, 1974; LEVI, 1975; VICTORIA Fo et alii, 1976; PACHECO, 1977 e BIANCO, 1978), Eleusine in dica (LEIDERMAN et alii, 1963; LEIDERMAN e SANTOS, 1964; FORS TER e DEUBER, 1970; GRASSI et alii, 1973; GRASSI e LEIDERMAN, 1974; LEVI, 1975; SADER, 1975 e BIANCO, 1978), Portulaca ole racea (OMETO, 1960; LEIDERMAN et alii, 1963; LEIDERMAN e SAN TOS, 1964; SANTOS et alii, 1967; FORSTER, 1968; LEVI, 1975 e BIANCO, 1978), Acanthospermum hispidum DC. (LEIDERMAN e SAN TOS, 1964; CAMARGO, 1974; GRASSI e LEIDERMAN, 1974; LEVI, 1975; SADER, 1975; VICTŌRIA Fo et alii, 1976 e BIANCO, 1978), Richatdia brasiliensis Gomez (OMETO, 1960; LJEDERMAN et alii, 1963; FORSTER, 1968; FORSTER e DEUBER, 1970; LEIDERMAN et alii, 1974; LEVI, 1975 e BIANCO, 1978), Brachiaria plantagi nea (Link.) Hitch (LEIDERMAN e SANTOS, 1964; GRASSI et alii, 1970; LEVI, 1975; VICTÓRIA Fo et alii, 1976 e BIANCO, 1978), Acanthospermum australe (Loef.) O. Kuntze (FORSTER, 1968; LEIDERMAN et alii, 1974; LEVI, 1975 e BIANCO, 1978). Obser va-se, no Brasil, um equilíbrio entre mono e dicotiledôneas, com relação à ocorrência em cultura do amendoim.

DRENNAM e JENNINGS (1977) verificaram que a supressão das plantas daninhas da família Gramineae foi o fa tor preponderante do aumento de produção da cultura do amen 
doim. As que mais afetaram a produtividade da cultura foram Brachiaria eruciformis (Sm.) Griseb. e Ischaemum afrum (Gmel.) Dandy. Das Dicotiledoneae a que mais afetou a produção foi ocimum brasilicum L.. Este fato está correlacionando à predo minância destas espécies na ārea cultivada.

A densidade e distribuição das plantas dani nhas, tambēm são fatores importantes na determinação do grau de competição. DRENNAN e JENNINGS (1977) verificaram que pro duções de vageirs semelhantes àquelas das parcelas sem competí ção, apenas foram observadas em parcelas em que a cobertura do solo, pela comunidade infestante era inferior a $10 \%$ por ocasião da 10â semana após a semeadura do amendoim. Contudo, não encontraram correlação direta entre o decréscimo de prodụ ção da cultura e a incidência de plantas daninhas avaliada em termos de cobertura do solo. Acreditam os autores, uma vez que'a maior parte das plantas presentes eram gramineas, que as mesmas conclusões poderiam ser obtidas se a avaliação fos se feita em termos de número de plantas ou peso da matéria sé ca por unidade de área, inclusive os maiores decréscimos de produção geralmente eram associados a menores porcentagens de cobertura do solo. Acredita-se que esta afirmação depende do hábito de crescimento das espécies presentes.

YORK e COBLE (1977) verificaram que una planta de Panicum dichotomiflorum a cada 5,0 m de sulco de semeadura provoca um decréscimo de $25 \%$ da produção de vagens da cultura do amendoim. Em densidades maiores da planta daninha, as per das de produção também são maiores. i importante salientar 
que esta gramínea apresenta um porte bastante superior

ao amendoim .

BIANCO (1978), estudando os efeitos da competi ção das plantas daninhas.e da adubação sobre a cultura do amendoim, procurou correlacionar o peso da matéria seca acumu lada pela comunidade infestante em diferentes fases do ciclo de desenvolvimento da cultura e o peso da produção de vagens. Não obser̃vou correlações significativas em nenhuma época. Quando as correlações foram feitas com relação à porcentagem de decréscimo de produção, apenas encontrou significância com a matéría seca acumulada. pela comunidade infestante até os 21 dias do ciclo da cultura. Deve-se observar que as parcelas mantidas no mato, eram submetidas a diferentes condições de adubação. HAUSER e PARHAM (1969) em outras condições observa ram correlação positiva entre incidência de plantas daninhas e decréscimo de produção da cultura do amendoim.

Os efeitos da associação entre comunidade in festante e cultura comercial podem ser incrementados ou mini mizados por algumas práticas culturais. HAUSER et aliz (1975) acreditam que toda e qualquer prática cultural que favoreça o crescimento e desenvolvimento da cultura do amendoim, aumenta o seu potencial competitivo. Em contrapartida verificaram que, em geral, os maiores decréscimos de produção, devidos a compe tição, ocorriam quando as condições para o desenvolvimento da cultura eram ōtimas. Isto pode ser explicado pela ocorrência de dois fatos. Primeiramente, o decréscimo de produção è to mado em relação à testemunha no limpo que, devido às condí 
ções ötimas, produziu acima do normal. Fm segundo lugar, quan do as condições são ōtimas para a cultura comercial, também o são para a maioría das espécies daninhas presentes, e, com isso, aumentam exponencialmente o potencial competitivo des tas ūltimas, muito mais eficientes na utilização dos recursos do meio.

HAUSER e PARHAM (1969) estudaram durante oito anos a competição entre plantas daninhas e a cultura do amen doim. Durante todo este período encontraram muitas variações nos resultados observados. Atribuiram estas variações à modi ficações no preparo do solo, variações nos métodos de aplica ção de fertilizantes, diferentes cultivares utilizados, modi ficações nos espaçamentos entre sulcos de semeadura e varia ções nas condjções climáticas a que cada experimento foi sub metido. Nenhuma relação causa-efeito foi observada, pertinen te aos efeitos destas variações sobre as relações competiti vas do amendoim com a comunidade infestante.

FEAKIN (1973) sugeriu algumas práticas que po dem ser utilizadas em favor da cultura, como a utilização de cultivares mais tolerantes à competição, plantio de sementes de alta qualidade e livre de doenças e, ainda, ajustar a épo ca de plantio a fim de obter un crescimento vigoroso da cultu ra.

A prática da adubação pode alterar as relações. competitivas entre cultura e comunidade infestante, uma vez que torna menos limitados alguns recursos do meio. Entretanto, pode incrementar o crescimento das plantas aumentando a compe 
tição por outros fatores não adicionados, como é o caso de elementos que não foram fornecidos ao solo, da água e da luz. Geralmente, a prática da colocação do adubo junto ao sulco de semeadura facilita o acesso e utilizàção dos adubos por parte da cultura e, como conseqüência, aumentia o seu potencial com petitivo (HAUSER e PARHAM, 1969). Quando as plantas daninhas são bem controladas, os requerimentos de fertilizantes, por parte da cultura do amendoim, são bem menores (JENNINGS, 1974). BIANCO (1978), estudando os efeitos da competi ção das plantas daninhas sobre a cultura do amendoim, sendo que esta última havia sido submetida a diferentes condições de adubação, observou que, os pesos da produção de vagens e de sementes por unidade de área foram alterados significativamen te pelas interações NP (nitrogênio-fósforo) e NK (nitrogêniopotássio), quando a cultura desenvolvia-se na ausência de plantas daninhas. Entretanto, na presença da comunidade infes tante estes efeitos não foram observados. O peso da produção de vagens por planta tambëm foi influenciado pela interação NP, o que não ocorreu na presença do mato. Acredita o autor, que a comunidade infestante apresentou maior capacidade de absorção de nutrientes anulando os efeitos da adubação.

o tipo de cultivo utilizado no desenvolvimento da cultura pode alterar as suas relações competitivas com a comunidade infestante. HAUSER e PARHAM (1969) observaram que o cultivo com amontoa favorece o estabelecimento e desenvolví mento do patógeno na "Murcha do sclerotium" e diminue a compe tividade da cultura. 
o tratamento fitossanitário aplicado com corre ção pode favorecer a cultura, sem contudo alterar a competi tividade da comunidade infestante. Para HAUSER et alii (1975) o controle de pragas e moléstias é importante no desenvolvi mento da folhagem que deverá sombrear eficientemente o solo . Contudo, o uso intensivo de pesticidas poderá provocar injụ rias à cultura e diminuir sua competitividade.

BUCHAHAM et alii. (1976) tentaram a utilização do fito-regulador SADH (äcido succínico-2, 2-dimetil hidrazi da) para alterar o hábito de crescimento do amendoinzeiro e verificar se com isso sua competitividade seria alterada. Não observaram influências do produto sobre as relações competiti vas da cultura com a comunidade infestante. Os autores tenta ram explicar os resultados pela suposição de que quando o pro duto foi aplicado, as influências da competição jā haviam sì do èstabelecidas.

As condições climáticas podem também alterar o grau de competição. para DRENNAM e JENNINGS (1977) o contrọ le da comunidade infestante torna-se mais importante em anos em que as condições de crescimento não são favoráveis à cultụ ra. FEAKIN (1973) observa que o período de controle das plan tas daninhas deve ser maior em anos em que a umidade torna-se fator: limitante à cultura.

Com relação ao tempo de competição entre a cul tura de amendoim e a comunidade infestante, os estudos visam, principalmente, a determinação de dois tipos de período: (a) o período, a partir da semeadura ou da emergência no qual a 
cultura deve permanecer livre da presença de plantas daninhas, a fim de que sua produção não seja alterada significativamen te e (b) o período, a partir da semeadura ou da emergência, no qual a cultura pode conviver com a comunidade infestante sem que sua produção seja alterada significativamente. Estes pe ríodos serão designados, no presente trabalho, por (a) perío do no limpo e (b) período no mato, respectivamente.

o período em que a cultura do amendoim deve ser mantida no limpo é dependente da maṇifestação de inümeros Eatores. Utilizando-se a mesma variedade e mesma têcnica de cultivo, este período pode variar com o local (HAUSER et alii, 1975 e BUCHANAM et alii, 1976) e com o ano agrícola (HILL e SANTELMANN, 1969; HAUSER et alii, 1975 e BUCHANAM et alii, 1976). Em anos em que a umidade é fator limitante este perío do deve ser maior (FEAKIN, 1973).

Geralmente, logo após o preparo do solo para o plantio da cultura, as plantas daninhas têm melhores condi ções de germinação e, com isso; a maior parte dos indivíduos componentes da comunidade infestante germinam quase ao mesmo tempo que a cultura. "BHAN et alii (1971) verificaram que nor malmente 75\% das plantas daninhas germinam durante os primei ros 30 dias de idade da cultura. Com isso, a manutenção no limpo durante os primeiros 30 dias eliminaria 75응 da comunida de infestante, em termos de nümero de indivíduos.

Este período depende, também, ẻe composição específica da comunidade infestante. BUCHANAM et alii (1976) verificaram que quando a cultuxa do amendoim competia com 
Cassia obtusufolia, a manutenção no limpo deveria ser maior em relação a quando a cultura competia com Desmodium tortuo sum. YORK e COBLE (1977), trabalhando com Panicum dichotomi florum, uma planta de porte bastantè superior ao do amendoim, verificaram a necessidade de um período no limpo acima de 8 semanas, embora o período de 2 semanas, após a germinação, fos se o mais critico.

ORAM (1961), usando herbicidas de baixo poder residual, até 10 dias após a emergência da cultura, verificou que plantas daninhas perenes, principalmente Cynodon dactyzon e Cyperus sp, as quais germinaram após este período, afetaram negativamente a produção.

Considerando comunidades infestantes naturais, pelos motivos já expostos, os períodos no limpo requeridos são um tanto diferentes. DRENNAM e JENNINGS (1977) encontraram um valor de 10 semanas. BUCHANAM et ali $i$ (1976) e BAHN e SINGH (1971), dependendo do local e do ano agrícola, encontra ram valores variando entre 4 e 8 semanas. Do mesmo modo dos autores anteriores, HAUSER et alii (1975) verificaram perío dos variando entre 2 e 4 semanas. HILL e SANTELMANN observaram que o período no limpo deveria ser de 6 semanas. Períodos maïores, de aproximadamente 7 semanas (45 dias) e de 8 semanas, foram encontrados por SCHILLER et alii (1976) e RETHINAM et alii (1976). Alguns destes valores dependem dos intervalos de tempo considerados pelos diversos autores. Al guns esquematizaram seus tratamentos com intervalos semanais enquanto que para outros os intervalos abrangiam 2 semanas. 
No Brasil, PACHECO (1977) concluiu que, nas condições em que desenvolveu seu experimento, o período no limpo deveria ser inferior a 5 dias, uma vez que as parcelas mantidas no limpo por 5 días (menor período considerado) e as parcelas mantidas no limpo por todo o ciclo de desenvolvimen to, apresentaram poduções estatisticamente semelhantes.

Alguns autores verificaram que a produção de forragem é menos sensível à competição que a produção de va gens, freqüentemente exigindo um menor período no limpo (HILL e SANTELMANN, 1969; HAUSER et alii, 1975 e YORK e COBIE, 1977). A exempló do período no limpo o período em que a cultura pode permanecer em competição com a vegetação infestante, a partir da germinação ou semeadura, depende do grau de intervenção de inúmeros outros fatores, que afetam a competitividade de ambos, cultura e plantas daninhas. Isto pode ser observado em experimentos realizados em 2 anos dife rentes (YORK e COBLE, 1977) ou quando as comunidades infes tantes apresentam composições específicas diferentes (HAUSER et alii, 1975). Também no caso do período no mato, a produ ção de forragem é menos sensivel à competição que a produção de vagens, freqüentemente permitindo um maior período no ma to sem sofrer danos significativos (HILL e SANTELMANN; 1969). YORK e COBLE (1977), estudando a competição en tre a cultura do amendoim e Panicum dichotomiflorum, uma gran mínea de grande vigor vegetativo, verificaram que quando o pe ríodo de convivência múltipla era acima de 2 semanas, a par tir da germinação da cultura, esta ültima sofria prejuízos sig 
nificativos na produção de vagens. Este foi o menor período encontrado na literatura consultada. Os maiores períodos tam bēm foram encontrados em trabalhos que estudavam a competição da cultura com apenas uma espécie daninha, Cassia obtusifolia, sendo este período de 10 a 14 semanas (HAUSER et alii, 1973). Em estudos de competição com comunidades naturais, os perío dos variam entre 3 e 8 semanas, à saber: 3 semanas (BHAM et a $i$ i, 1971 e HILL e SANTELMANN, 1969), 6 semanas (HAMMERTON, 1974; DRENNAN e JENNINGS, 1977) e 8 semanas (BUUNTING e LEA, 1957).

o período crítico de competição foi muito pou co estudado. DRENNAN e JENNINGS (1977), baseados em resulta dos próprios e na literatura existente, concluiram que um con trole efetivo dá comunidade infestante deve ser feito durante todo o período compreendido entre a quarta e a décima semara do ciclo de desenvolvimento do amendoim. RODRIGUES MARQUINA et alii (1974), na Argentina, verificaram que este período de veria ser entre 30 e 60 dias a partir da semeadura. Realmente há uma relativa concordância nos resultados obtidos pelos au tores.

Assim, da intensidade das manifestações dos di versos fatores do meio e dos fatores inerentes à cultura, à comunidade infestante ou a ambos, tem-se o grau de competição, o qual normalmente é descrito, com relação à espécie comer cial estudada, pelo decréscimo percentual do peso da produção de vagens da parcela no mato em relação à parcela no limpo dụ rante todo o ciclo de desenvolvimento. Os valores médios ob- 
servados pelos diversos autores são os seguintes: 20\% (HAUSER e PARHAM, 1961), 31\% (HAMMERTON, 1974), 40-44\% (Boswell, 1966, citado por HILL e SANTELMANN, 1969), 50\% (ORAM, 1961), 65\% (BIANCO, 1978), 70\% (DRENNAN e JENINGS, 1977), 73\% (HAMDOUN, 1977) e 80\% (ISHAG, 1971).

A literatura é bastante clara para poder-se afirmar que o grau de manifestação de cada fator e da intera ção de fatores é extremamente variável com as condições eco lógicas nas quais a pesquisa foi desenvolvida. Assim torna se imprudente a utilização de resultados obtidos em outros lo cais e com outras cultivares, como é o caso da quase totalida de dos tratalhos consultados. No Brasil, encontrou-se o tra balho de PACHECo (1977) que estudou o período inicial no lim po que deveria ser crítico, numa região em que a composição específica da comunidade infestante e, principalmente os s으 los; são bastante diferentes daqueles no qual foi desenvolvi da a presente pesquisa. Saliente-se que, não se encontrou na literatura, neste tipo de pesquisa uma exploração maior dos efeitos da competição sobre os värios parâmetros produtivos da cultura do amendoim, sendo que a maioria dos trabalhos ape nas se preocupam com a produção de vagens e de forragem. Além disso, nenhum trabalho foi encontrado em que se estudou os efeitos de competição sobre a nutrição mineral do amendoim, principalente, com relação à composição química das sementes. 
4. MATERIAL E MÉTODOS

\subsection{Local}

O presente experimento foi instalado e conduzi do em área experimental da Faculdade de Ciências Agrárias e Veterinārias da Universidade Estadual Paulista "Julio de Mes quita Filho", "Campus" Universitário de Jaboticabal, SP.

\subsection{Solo}

O experimento foi instalado em solo pertencen te a unidade de mapeamento Latossol Vermelho Escuro - fase are nosa (COMISSÃO DE SOLOS, 1960) e a nível de série classifica do por ALOISI E DEMATTE (1974) como pertencente à série Santa Tereza, correspondendo ao sub-grupo "Typic Haplorthox" da 7aㅡ aproximação. Trata-se de um solo barro argiloso-arenoso, pH 5.8 , contendo $0,69 \%$ de carbono, 0,094 e.mg de $\mathrm{BO}_{4}^{-2} / 100 \mathrm{~g}$ de TFSE, 0,14 e.mg de $\mathrm{K}^{+} / 100 \mathrm{~g}$ de TFSE, 2,08 e.mg de $\mathrm{Ca}^{++} / 100 \mathrm{~g}$ de TFSE, 0,64 e.mg de $\mathrm{Mg}^{++} / 100 \mathrm{~g}$ de TFSE, 0,096 e.mg de 
$\mathrm{Al}^{+++} / 100 \mathrm{~g}$ de TFSE e 2,64 e.mg de $\mathrm{H}^{+} / 100 \mathrm{~g}$ de TFSE.

E importante esclarecer que este solo é inten samente utilizado na cultura desta leguminosa na região de Ja boticabal e Luzitania (SP) .

\subsection{Preparo do solo}

O solo, anteriormente, havia sido utilizado co mo pastagem, sendo Pennisetum purpureum I. Rich. Pers. (Capim napier) a espécie forrageira cultivada. A destruição da pas tagem foi realizada em meados de abril e o preparo do solo pa ra a instalação do experimento apenas foi iniciado nos primei ros dias de outubro. Neste intervalo apareceram algumas es pécies daninhas, sendo as mais comuns: Brachiaria plantaginea, Indigofera hirsuta L. e sida sp. O solo foi arado e gradeado duas vezes. Os sulcos de semeadura foram feitos com um sulca dor acoplado a um microtrator, guardando-se um espaço de $0,60 \mathrm{~m}$ entre as Iinhas de semeadura.

4.4. Semeadura

A semeadura foi realizada no dia 23 de outubro de 1976, utïlizando-se a cultivar 'Tatü-53', com sementes classificadas com peneira 18 e adquiridas no Posto de Semen tes da Secretaria de Agricultura do Estado de São Paulo. A adubação de plantio foi $300 \mathrm{~kg} / \mathrm{ha}$ da fórmula 4 - 34 - ll. A se meadura foi realizada manualmente para melhor uniformidade da cultura, depositando-se 30 sementes por metro linear de sulco. 
A germinação ocorreu entre 29/10/1976 a 01/11/1976.

\subsection{Tratamentos}

De acordo 'com as finalidades do experimento, instalou-se o ensaio com 2 grupos de tratamentos. No primei ro, a cultura permaneceu livre da competição das plantas daní nhas des de a germinação até diferentes épocas de seu ciclo de desenvolvimento, a saber: $0,10,20,30,40,50,60,70,80$, 90 e 100 dias. Após estes estágios, as plantas daninhas que germinassem eram deixadas crescer lịvremente. No segundo gru po de tratamentos, ocorreu o contrário. A cultura permaneceu em competição, com a comunidade infestante desde a germinação atē diferentes estágios de seu ciclo de desenvolvimento: 0 , $10,20,30,40,50,60,70,80,90$ e 100 dias. Após estes es tágios removiam-se as plantas daninhas presentes na ārea da parcela e impedia-se o desenvolvimento de outras, até a co lheita.

Para maior facilidade em expressar os diferen tes tratamentos utilizou-se dos termos (a) no mato e (b) no limpo, para exprimir o período em presença e o período livre da presença da comunidade infestante, respectivamente.

As parcelas eram mantidas livres da presença de plantas daninhas através de vistorias a cada 2 dias, ocasião em que as plantas daninhas emergentes eram arrancadas à mão, para não prejudicar a estrutura do solo.

Para efeito da aplicação dos tratamentos pro 
postos considerou-se que a emergência ocorreu no dia 30/10/ 1976, quando mais de 75\% das plantas de amendoim já haviam emergido.

4.6. Delineamento experimental

O experimento, no campo, obedeceu o delineamen to experimental de blocos casualizados, com 3 repetições. As parcelas experimentais constituiram-se de 5 linhas de semeadu ra com $4 \mathrm{~m}$ de comprimento $\left(12 \mathrm{~m}^{2}\right)$. Para a área útil de cada parcela, considerou-se as 3 linhas centrais, desprezando - se $0,5 \mathrm{~m}$ nas extremidades como bordadura $\left(5,4 \mathrm{~m}^{2}\right)$.

\subsection{Tratamento fitossanitário}

Para o controle de pragas e moléstias realiza ram-se pulverizações periódicas, com pulverizador costal muni do de bico D2-13, a saber: (a) no dia 12/10/1976, realizou-se uma pulverização com Nuvacron ( $80 \mathrm{ml} / 100 \ell$ de água) e Iharagen (10 ml/100 l de āgua) e no dia 29/10/1976 foi efetuada a se gunda pulverização com Sumithion ( $150 \mathrm{ml} / 100 \ell$ de água) e Iha ragen, na mesma dosagem anterior.

4.8. Observações sobre a comunidade infestante

Nos tratamentos em que a cultura permanecia um período inicial no mato, a cada 10 dias, para os tratamentos respectivos, colhia-se as plantas daninhas presentes em uma 
area de 0,32 $\mathrm{m}^{2}$ centrais de cada parcela. Estas plantas eram identificadas, contadas, acondicionadas em sacos de polietile no e levadas ao laboratório. O restante da parcela era ime diatamente limpo.

No final do ciclo (27/02/1977) nas parcelas em que a cultura permaneceu um período inicial no limpo, as plan tas daninhas foram colhidas em ārea, também, de $0,32 \mathrm{~m}^{2}$ no centro das parcelas experimentais. A exemplo do outro grupo de tratamentos, as plantas daninhás eram identificadas, conta das, acondicionadas em sacos de polietileno e levadas ao labo ratório.

$$
\text { No laboratório, as plantas eram lavadas em }
$$
āgua corrente e acondicionadas em sacos de papel devidamente etiquetados. Depois eram secas em estufa da circulação força da de ar (FANEM modelo $330 / 5$ ) a $60-70^{\circ} \mathrm{C}$, até peso constnate. o peso da matéria seca foi determinado com balança tipo Dial0-Gram, com precisão de $0,1 \mathrm{~g}$.

4.9. Observações sobre a produção da cultura do amendoim No dia 27/02/1977, exatamente 134 điias após a semeadura, colheu-se as plantas de amendoim presentes na área útil de cada parcela. A seguir, procedeu-se a contagem do nū mero de plantas. Logo após foram dispostas, em forma de fei xes invertidos para que as vagens secassem ao sol. No dia se guinte, 'separou-se manualmente as plantas das vagens. Estas últimas foram acondicionadas em sacos de papel devidamente eti 
quetados e levados ao laboratório. As vagens ainda foram de $\underline{i}$ xadas secar à sombra por 5 dias. Após este período, determi nou-se o peso da produção de vagens com balança tipo Dial-0Gram, com sensibilidade de $0,1 \mathrm{~g}$.

Após a pesagem, procedeu-se a debulha manual separando-se a casca das sementes. Nesta operação avaliou-se o tamanho de vagens, determinando-se o número de sementes por vagem. Após a debulha, avaliou-se o peso das cascas e o peso da produção de sementes. Com estes dois últimos valores de terminou-se a porcentagem de casca.

As sementes foram separadas em um classificador de diâmetro de grãos, utilizando-se peneiras de 18 a $22 / 64$ de polegada de diâmetro de crivo. Após a classificação das se mentes, cada classe de diâmetro foi pesada separadamente.

Com os dados obtidos calculou-se ainda: (a) pe so da produção de vagens por planta, (b) peso da produção de sementes por planta, (c) número de vagens por planta, (ã) nú mero de vagens com diversos tamanhos por planta, (e) peso de grãos classificados em diferentes peneiras por planta. Com esses dois últimos parâmetros, calculou-se ainda (a) distrí buição porcentual de vagens de diferentes tamanhos e (b) dis tribuição porcentual de sementes de diferentes diâmetros, res pectivamente.

4.10. Parâmetrós climatológicos

Os parâmetros meteorológicos de temperaturas 
máxima, média e mínima diárias e de precipitação diária foram obtidos no Posto Meteorológico da Faculdade de Ciências Agrạ rias e Veterinárias "Campus" de Jaboticabal, localizada à aproximadamente, $1 \mathrm{~km}$ do.local em que foi instalado o experí mento. Estes dados estão apresentados graficamente nas Figu ras 1 a 5

\subsection{Análise química das sementes}

As sementes, após as avaliações dos parâmetros produtivos, foram lavadas, secadas, moídas e analisadas para nitrogênio, fósforo, potássio, cálcio e magnésio, segundo mé todos propostos por SARRUGE \& HAAG (1972).

\subsection{Tratamento estatístico dos dados}

Os resultados obtidos, referentes aos parâme tros de produção da cultura do amendoim, foram submetidos à análise de variância segundo o teste $F$ e, quando este último era significativo, utilizou-se o teste de Tukey para compara ção das médias.

Ainda procedeu-se o desdobramento dos graus de liberdade dos tratamentos, comparando-se inicialmente os tra tamentos que tiveram um período inicial no limpo com aqueles que tiveram um período inicial no mato. E bom esclarecer que pela prōpria natureza da pesquisa, este último grupo de trata mentos sofreu de maneira mais intensa a competição imposta pe las plantas daninhas, as quais germinaram praticamente ao mes 
mo tempo do amendoim. Para facilidade em expressar o contras te, utilizou-se nas tabelas a conotação "L contra M".

Outro contraste foi realizado entre todos os tratamentos que tiveram um período inicial no limpo. A cono tação usada foi "Dentro L". Um terceiro contraste foi elabo rado para comparar as parcelas com um período inicial no mato e a conotação utilizada foi "Dentro M".

Em alguns parâmetros, em que a bibliografia era suficiente para discutir-se mais detalhadamente os efeitos do período de competição, estudou-se a correlação linear entre diferentes períodos de competição e a expressão dos parâme tros. Nesta análise a regressão linear foi estudada pelo mé todo dos polinômios ortogonais descrito por PIMENTEL GOMES (1970). 

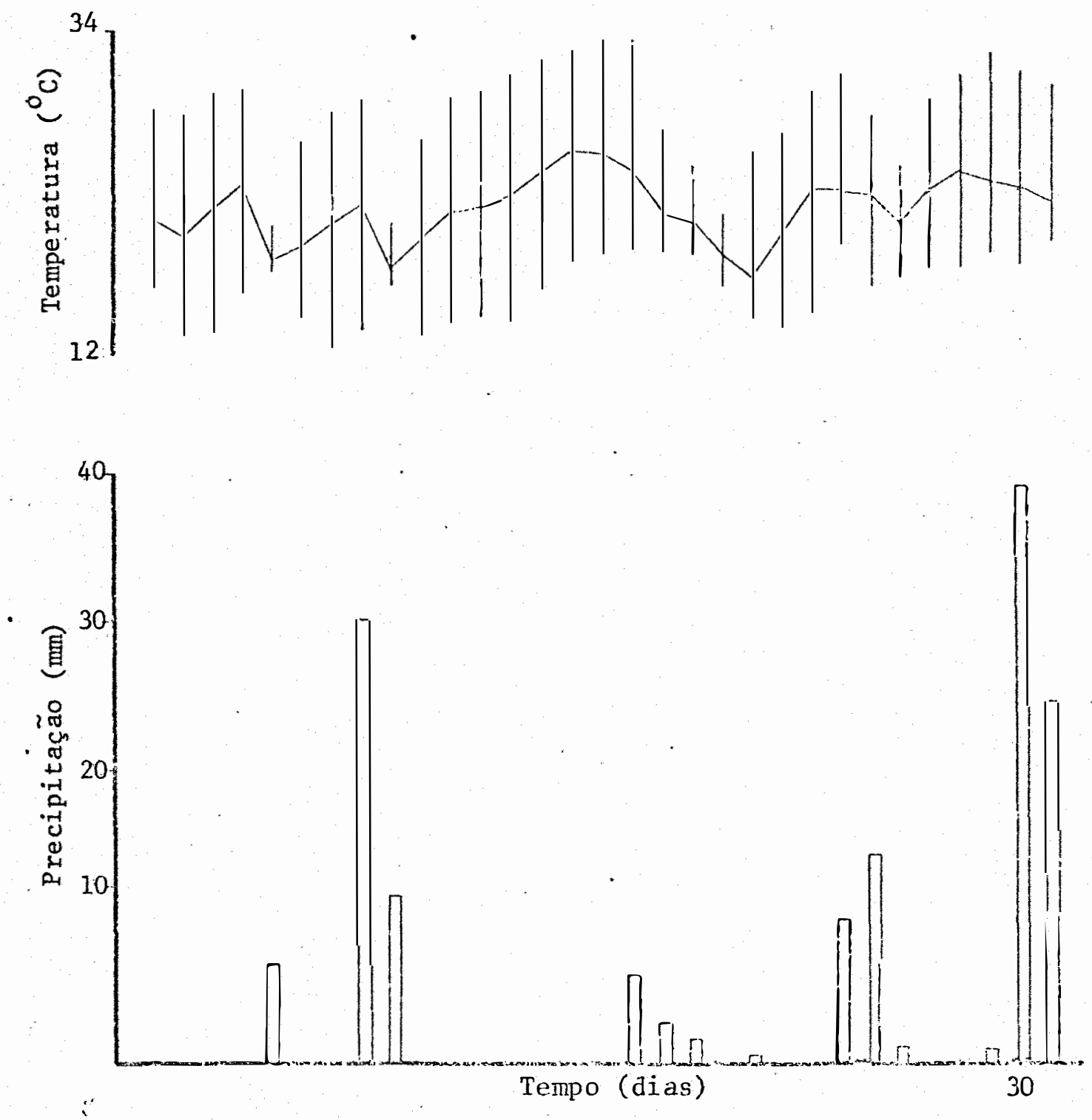

FIGURA 1 -Amplitudes das variações tērmicas (linhas verticais), temperaturas médias diărias (linha contínua) e pre cipitações diārias (barras verticais) ocorridas no mês de outubro de 1976 na FCAV/UNESP, Jaboticabal.

- Temperatura média mensal de $22,0^{\circ} \mathrm{C}$ e precipitação to tal do mês $149,3 \mathrm{~mm}$. 
29.
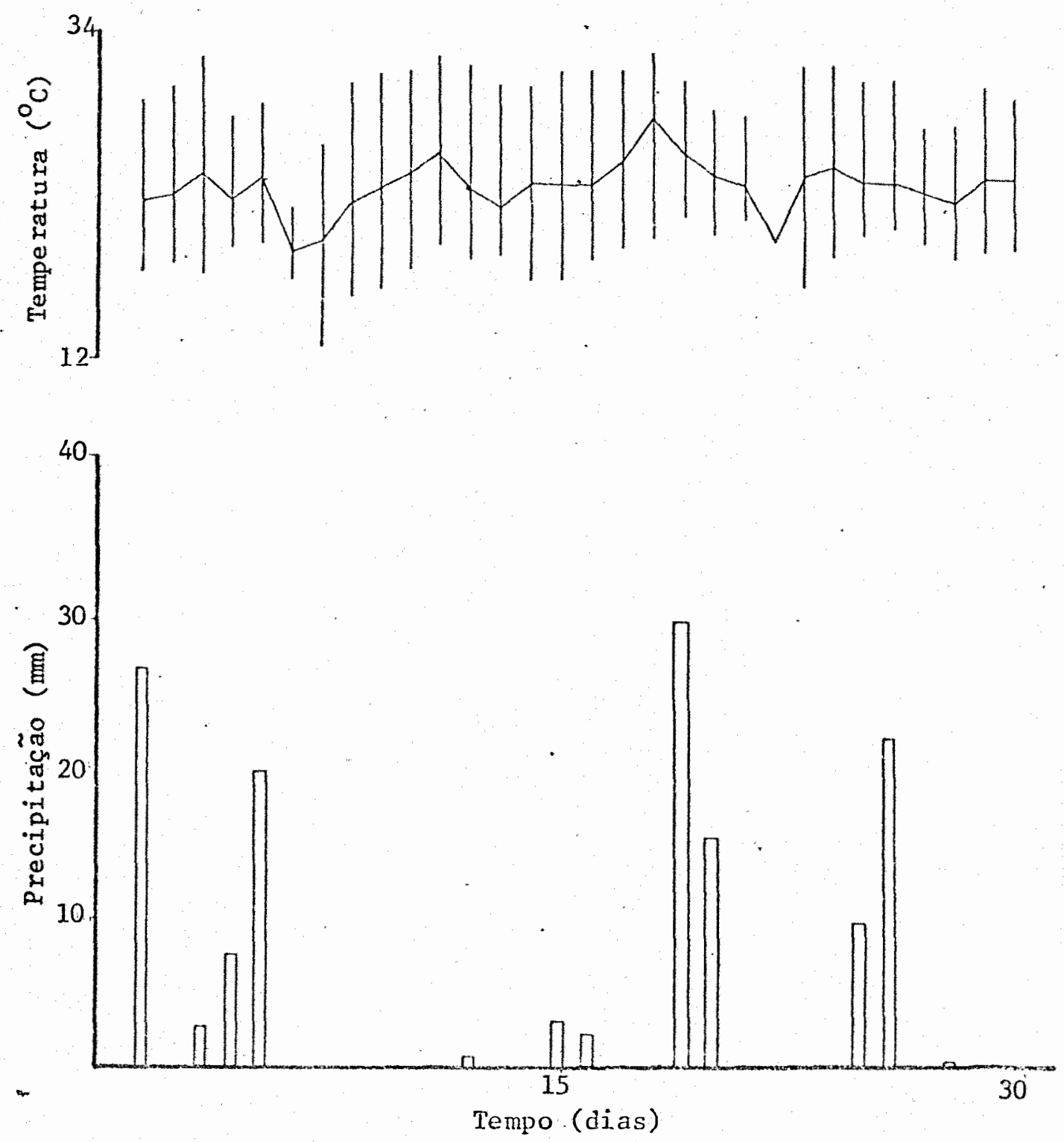

FIGURA 2 - Amplitudes das variações térmicas (linhas verticais), temperaturas médias diārias (linha contínua) e pre cipitações diārias (barras verticais) ocorriclas no nềs de novembro de 1976 na FCAV/UNESP, Jaboticabal. Temperatura média mensal de $23,3^{\circ} \mathrm{C}$ e precipitação to tal do mès $140,7 \cdot \mathrm{mm}$. 

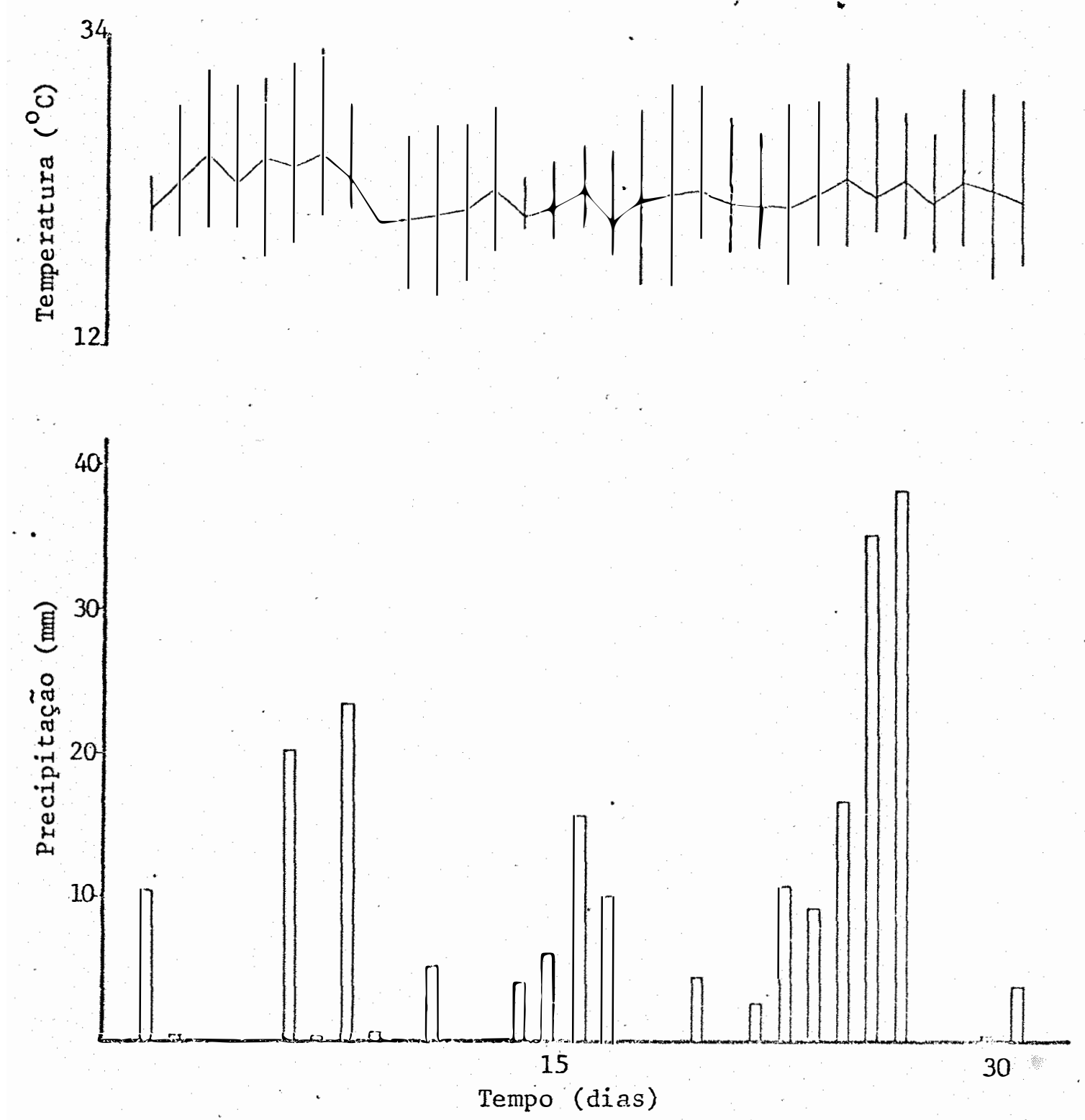

FIGURA 3 - Amplitudes das variações térmicas (linhas verticais), temperaturas médias diárias (linha contínua) e pre cipitações diārias (barras verticais) ocorridas no mês de dezembro de 1976 na FCAV/UNESP, Jaboticabal. Temperatura média mensal de $24,0^{\circ} \mathrm{C}$ e precipitação to tal do mês $217,3 \mathrm{~mm}$. 


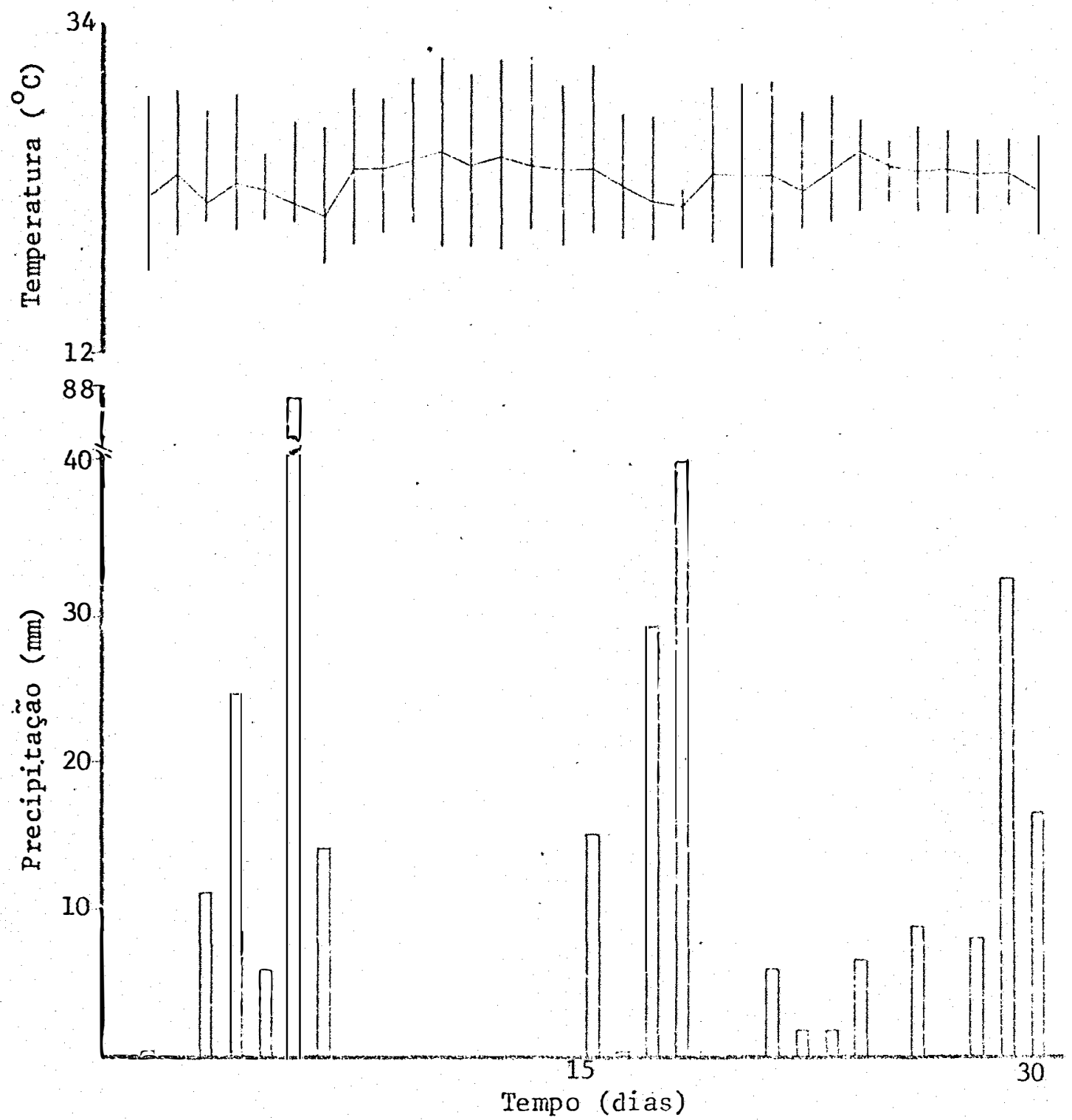

FIGURA 4 - Amplitudes das variações tērmicas (linhas verticais), temperaturas médias diārias (linha contínua) e pre cipitações diārias (barras verticais) ocorridas no mês de janeiro de 1977 na FCAV/UNESP, Jaboticabal.

- Temperatura média mensal de $23,8^{\circ} \mathrm{C}$ e precipitação to tal do mês $312,4 \mathrm{~mm}$. 

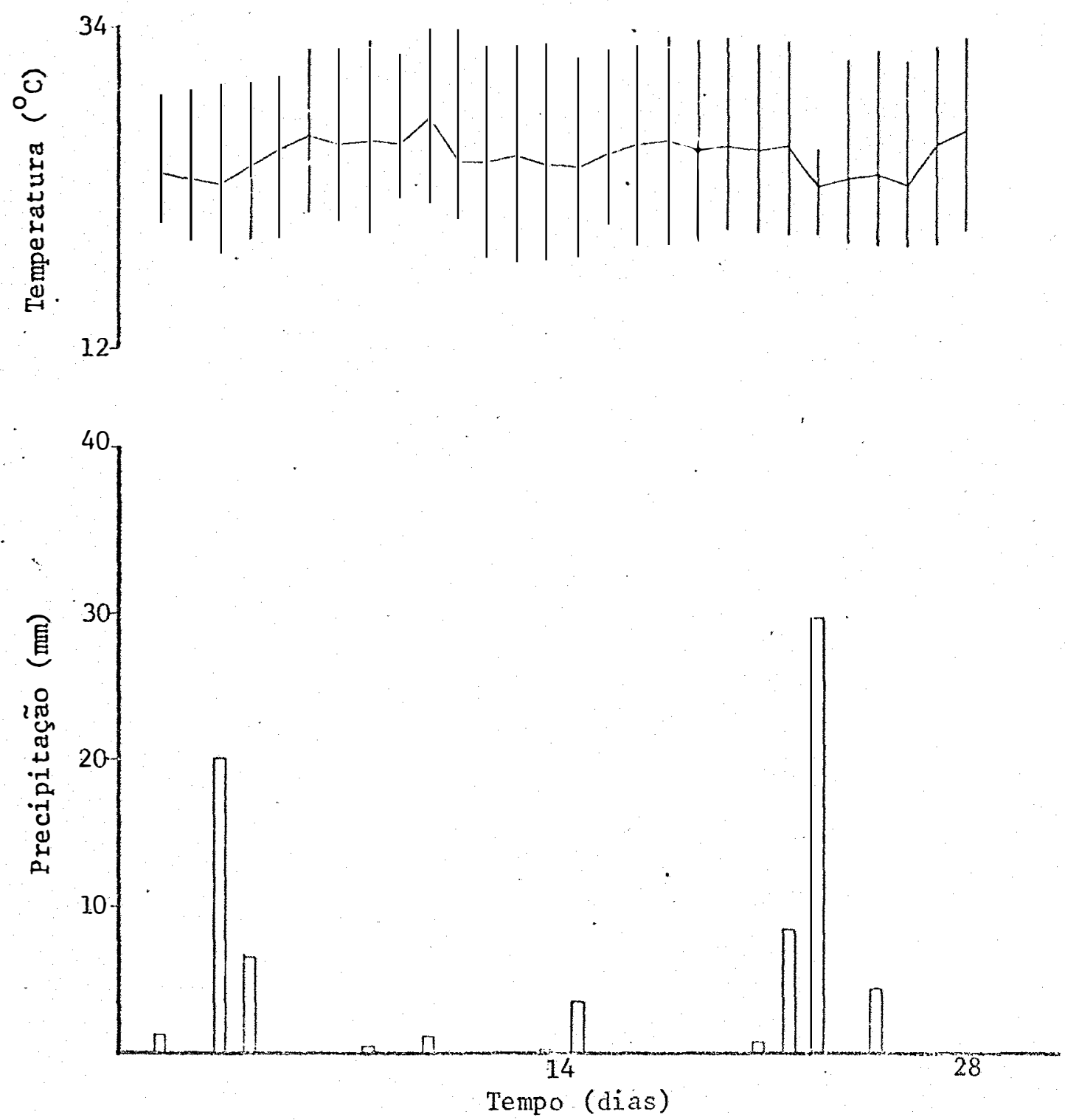

FIGURA 5 - Amplitudes das variações térmicas (linhas verticais), temperaturas médias diārias (linha contínua) e pre cipitações diārias (barras verticais) ocorridas no mês de fevereiro de 1977 na FCAV/UNESP, Jaboticabal. Temperatura média mensal de $25,0^{\circ} \mathrm{C}$ e precipitação to tal do mês $76,2 \mathrm{~mm}$. 
5. RESULTADOS E DISCUSS ÃO

As principais plantas daninhas que ocorreram na ārea experimental foram avaliadas, no caso do grupo de tra tamento com período inicial no mato, por ocasião do término do período de competição do tratamento respectivo. Os resul tados estão apresentados, à seguir, por espécie, seguido, en tre colchetes, dos tratamentos em que ócorreu, expressos em dias no mato. Em cada tratamento, o nümero de indivíduos da espēcie em questão observado nas três repetições, está aprẹ sentado entre parenteses logo à seguir ao tratamento.

Assim, no grupo de tratamentos com períodos iniciais no mato, as principais espēcies infestantes foram: Sida glaziovii K. Schuman $[10(15), 20(21), 30(17), \quad 40(34)$, $50(20), 60(15), 70(18), 80(11), 90(12)$ e $100(13)]$, Cenchrus echinatus $[10(32), 20(11), 30(44), 40(11), 50(21), 60(05)$, $70(21), 80(20), 90(11)$ e $100(04)]$, Digitaria sanguinalis $[50(14), 70(16)$ e $90(07)]$, Bidens pirosa [10(01), 30(05), e $90(01)]$, Tagetes minuta L. $[10(20), 50(07), 60(02), 70(03)$, 
$80(02), 90(01)$ e $100(07)]$, Brachiaria plantaginea [10(01), $20(01), 30(01), 40(01), 50(09), 70(24), 80(10)$ e $100(15)]$, In digofera hirsuta L. [10(07), 20(14), 30(22), 40(24), 50(11), $60(10), 70(09), 80(02), 90(11)$ e $100(06)]$, Richardia brasizí ensis $[10(27), 20(32), 30(08), 40(23), 50(03), 60(24), 70(09)$, $80(08)$ e $90(11)]$, Althernanthera ficoidea L. [30(02), 40(01) e 80(04)], Acanthospermumaustrale [30(02), 40(01), 60(02), $90(01)$ e 100(01)], Ipomoea aristolochiaefolia H.B.K. Don. [10(03) e 50(02)], Cassia patezraria DC. |10(01) e 50(02)|, Commelina erectaL. [30(01)], Melinis minutiflora Beauv. [10(06) e $30(11)]$, Eleusine indica [70(11)], Pennisetum sp $[80(06)]$, Solanum americanum $[40(01)]$ e Cyperus sp $[40(08)]$.

Considerando-se todo o grupo de tratamentos, em termos de número de indíviduos, as maiores populações foram, em ordem decrescente, as seguintes: Cenchrus echinatus, Sida glaziovii, Richardia brasiliensis, Indigoferahirsuta, Bra chiaria plantaginea, Digitaria sanguinalis e Tagetes minuta. Neste aspecto, houve uma predominância das Dicotiledoneas $(60,5 \%)$ em relação as Monocotiledoneas $(39,5 \%)$. Em termos de distribuição geográfica, a mais generalizada foi Sida gla ziovii ocorrendo em 93,3\% das parcelas deste grupo de trata mentos. Outras espécies de ampla distribuição e a porcentą gem de parcelas em que ocorreram são as seguintes: Cenchrus echinatus, 86,7\%; Indigofera hirsuta, 80,0\% e Richardia bra siliensis, 73,3\%. Todas as demais espécies ocorreram em menos de 50,0\% das parcelas deste grupo de tratamentos.

No grupo de tratamentos com período inicial no 
limpo, as avaliações foram feitas por ocasião da colheita da cultura. As principais espécies infestantes foram: Sida gla ziovii $[00(17), 10(13), 20(06), 30(05), 40(03)$, $50(10)$, $60(03), 70(07), 80(09), 90(04)$ e 100(01)], Cenchrus echinatus $[00(15), 10(06), 20(08), 30(08), 50(10) ; 60(09), \quad 70(03)$, $80(08), 90(20)$ e $100(04)]$, Digitaria sanguinalis [10(06), $20(08), 40(04), 50(01), 60(01), 70(01)$ e $80(01)]$, Bidens p $\underline{i}$ Zosa $[10(01), 50(01)$ e $80(01)]$, Tagetes minuta $[00(02), 10(02)$, $30(01), 70(01)$ e $90(01)]$, Brachiaria plantaginea [00(01), $40(10), 80(01), 90(03)$ e 100(04)], Indigofera hirsuta [00(09), $10(05), 20(08), 40(03), 50(01), 70(01)$ e 90(02)], Richardia brasiliensis $[00(17), 10(02), 20(01), 40(04), 50(02), 60(01)$, 70 (01). 90.(01). e 100(02)], Althernanthera ficoidea $[00(02), 10(12), 30(01), 80(02)$ e $90(01)]$, Acanthospermum aus trale $[50(01)]$, Ipomoea aristolochiaefolia $[00(01)]$, Commel $\underline{i}$ na erecta [30(03)], Mimosa pudica $[40(01)$ e $70(01)]$, Cassia tora $[20(01)$ e $100(01)]$, Rynchelitrum roseum [50(01)] Tri chachne insularis $[40(01)]$.

Considerando-se todo o conjunto de tratamentos em termos numéricos, houve um maior equilíbrio entre mono e dicotiledoneas, com uma leve predominância das primeiras $(51,7 \%)$ em relação às demais $(48,3 \%)$, ao contrário do que havia ocorrido no outro grupo de tratamentos. A ordem decres cente de predominância numérica das populações foi muito pou co alterada, sendo Cenchrus echinatus, Sida glaziovii, Richar dia brasiliensis, Indigofera hirsuta, Digitaria sanguinalis, Brachiaria plantaginea, Althernanthera ficoidea e Tagetes mi 
nuta. Também, neste grupo de tratamentos Sida glaziovii foi a que apresentou distribuição mais generalizada ocorrendo em 75,8\% das parcelas, seguindo-se Cenchrus echinatus 63,6\%. To das as demais espécies ocorreram em menos de 50,0\% das parce las deste grupo de tratamentos.

Os resultados mostram que as espécies ocorre ram de modo mais ou menos indiferente em ambos os grupos de tratamentos, sendo que nogrupo de tratamentos com um períocio inicial no limpo as populações foram menores, o que é lógico, uma vez que a avaliação foi feita após um período, se bem que variável, de controle destas plantas e no outro grupo as ava liações foram feitas antes que houvesse qualquer controle de mato. Segundo as observações de BHAN et alii (1971) a maior parte dos indivíduos componentes de uma comunidade infestante em amendoim, germinam nos primeiros 30 dias do ciclo da cultu ra. Então um controle inicial do mato diminue drasticamente os efetivos das populações componentes desta comunidade.

As principais espécies presentes são amplamen te citadas na literatura ocorrendo nesta cultura, exceção fei ta à Sida graziovii. são citáas duas espēcies deste mesmo gênero, ou seja, Sida spinosa (SADER, 1975) e Sida rhombifo Iia (FORSTER, 1966). De acordo com o que já foi discutido na revisão bibliográfica, para as condições brasileiras ocorre um equilibrio entre mono e dicoliledoneas, em termos de ocor rência na culutra de amendoim.

A matéria seca acumulada pelas plantas dani nhas foi avaliada em conjunto e os resultados estão apresenta 
dos na Tabela 1. Considerando-se, para efeitos de comparação, apenas o tratamento com período total no mato, pode-se aquila tar que as infestações ora observadas são similares aquelas verificadas por ISHAG (1971). Ácredita-se que os resultados apresentados pelos demais autores tenham sidos tomados em ter mos de matéria fresca. Os valores observados foram bastante altos como 15,98 t/ha em 1975 e 22,39t/ha em 1974 (YORK e CO BLE, 1977), 20,80 t/ha (HAUSER et ali $i, 1975$ ) e $11,00 \mathrm{t} / \mathrm{ha}$ em 1966 e 22,00 t/ha em 1967 (HILL e SANTELMANN, 1969).

Na tabela 2 es.tão apresentados os dados médios de peso da produção de vagens e de sementes por parcela de $5,4 \mathrm{~m}^{2}$ e dados de porcentagem de casca.

Com relação ao peso de vagens por parcela ob servou-se que os tratamentos diferiram significativamente en tre si. O desdobramento dos graus de liberdade dos tratamentos mostrou que estas diferenças eram evidentes quando compa ravam-se tratamentos que tiveram um período inicial no limpo com aqueles que tiveram um período inicial no mato. Além dis so, dentro do grupo de tratamentos que tiveram um período ini cial no mato, houveram, também, contrastes que diferiram sig nificativamente. E claro que, pela própria natureza do traba 1ho, este último grupo de tratamentos sofreu mais intensamen te os efeitos da competição. Em média, as parcelas que tive ram um período inicial no limpo apresentaram um peso de va gens $15,8 \%$ mais elevado em relação ao grupo de,tratamentos com período inicial no mato, indiferentemente dos comprimentos dos períodos. 
TABELA 1 - Pesos mêdios da matéria seca acumulada pela comuni dade infestante em $0,32 \mathrm{~m}^{2}$ da área útil das parce las experimentais. Médias de 3 repetições.

\begin{tabular}{|c|c|c|}
\hline \multirow{2}{*}{$\begin{array}{l}\text { Tempo } \\
\text { (dias) }\end{array}$} & \multicolumn{2}{|c|}{ Peso da matéria seca $\left(\mathrm{g} / 0,32 \mathrm{~m}^{2}\right)$} \\
\hline & Mato & Limpo \\
\hline 00 & - & 71,2 \\
\hline 10 & 2,5 & 19,5 \\
\hline 20 & 3,3 & 3,5 \\
\hline 30 & 20,0 & 3,2 \\
\hline 40 & 17,8 & 3,1 \\
\hline 50 & 26,5 & 2,1 \\
\hline 60 & 32,4 & 0,6 \\
\hline 70 & 78,3 & 0,8 \\
\hline 80 & 72,3 & 3,1 \\
\hline 90 & 73,3 & 4,7 \\
\hline 100 & 231,1 & 1,0 \\
\hline F bloco & $1,79^{\mathrm{NS}}$ & $0,38^{\mathrm{NS}}$ \\
\hline F tratamento & $8,60 * *$ & $4,77 * *$ \\
\hline Reg. lo grau & $50,93 * *$ & $17,45 * *$ \\
\hline Reg. 29 grau & $12,49 * *$ & $16,68 * *$ \\
\hline Reg. 3: grau & $5,12 *$ & $9,39 * *$ \\
\hline Desvios de Reg. & $1,26^{\mathrm{NS}}$ & $0,60^{\mathrm{NS}}$ \\
\hline C.V. ( $\left(\frac{\circ}{0}\right)$ & 72,67 & 161,45 \\
\hline
\end{tabular}

* - Significativo ao nível de 5\% de probabilidade. ** - Significativo ao nível de $1 \%$ de probabilidade. NS - Não significativo. 


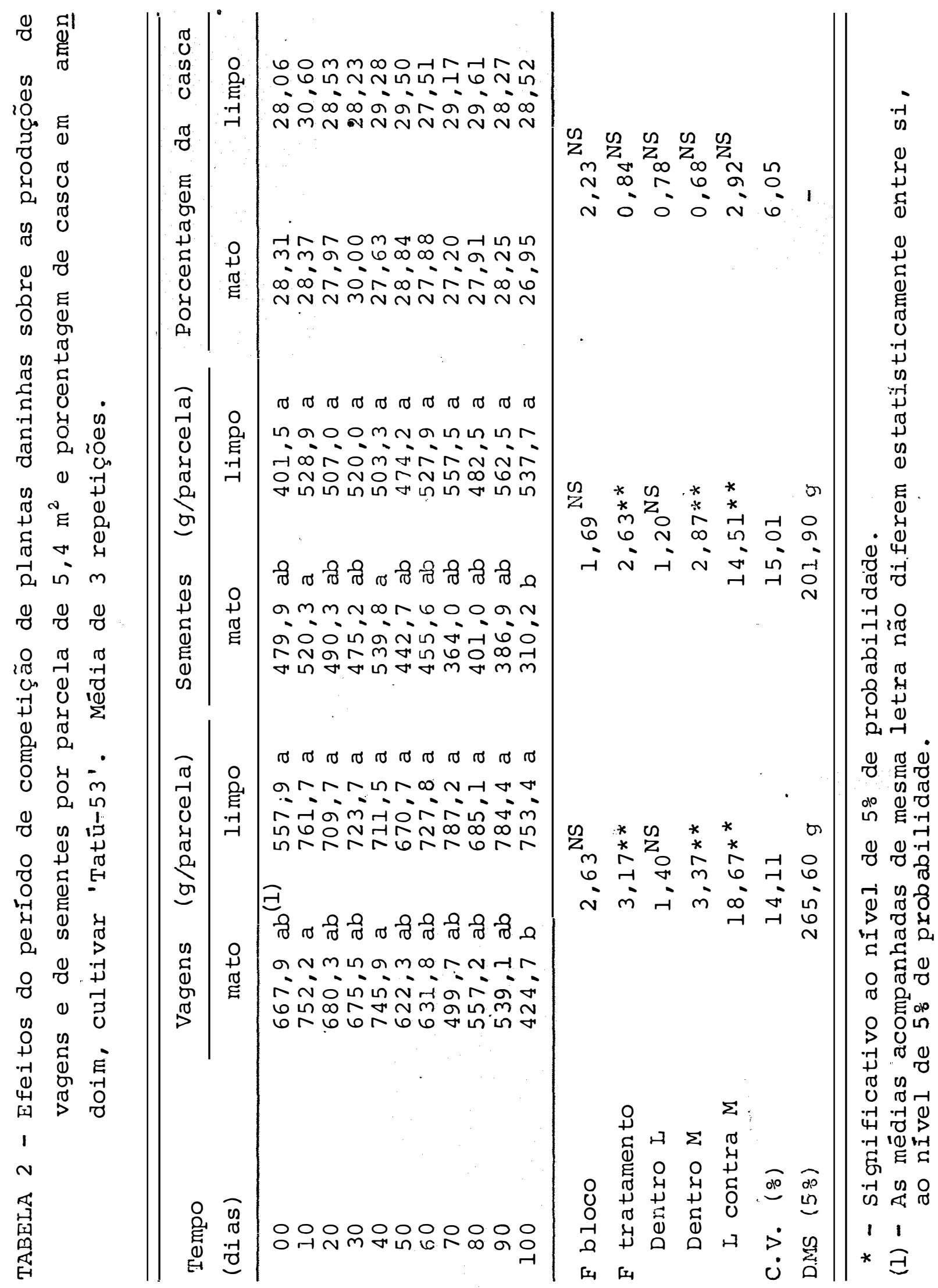


A correlação entre o peso da produção de

gens e o tempo em que as parcelas permaneceram no mato foi significativa $(r=0,83 * * ; v=749,84-2,64 t$, onde $\underline{v}$ è a produção de vagens da paxcela e $\underline{t}$ é o tempo, a partir da ge $\underline{r}$ minação, em que cultura e comunidade infestante permanecem em competição), indicando que o peso da produção de vagens de cresce proporcionalmente ao tempo de competição, a partir da germinação ou plantio. Observou-se também, uma correlação significativa entre o peso da matéria seca acumulada pelas plantas daninhas por ocasião da eliminação da comunidade in festante e o peso da produção de vagiens das parcelas corres pondentes $(r=0,87 * *, v=394,00-0,55 \mathrm{~m}$, onde $\underline{\mathrm{m}} \overline{\mathrm{e}} \mathrm{o}$ peso da matēria seca das plantas daninhas).

A análise de regressão múltipla entre estes três parâmetros foi significativa $\left(R^{2}=0,93 * *\right)$. A equação

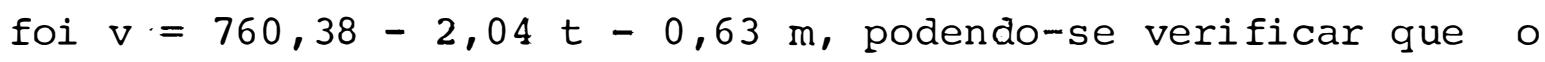
tempo de competição influiu em maior proporção na produção da cultura que o crescimento das plantas daninhas. Talvez isto se deva ao fato de que o próprio acúmulo de matéria seca das plantas daninhas dependeu do tempo que a comunidade infestan te teve para o desenvolvimento $(r=0,81 * *, m=34,85+0,36 t)$. As correlações entre o período de competição, a partir da germinação ou do plantio, e a produção de vagem da cultura do amendoim, já foram verificadas em outros trabą Ihos de pesquisa, destacando-se aqueles apresertados na Tabe la 3, calculados com dados contidos nos trabalhos de HAUSER et alii (1975) e HILL e SANTELMANN (1969). Em ambos traba 


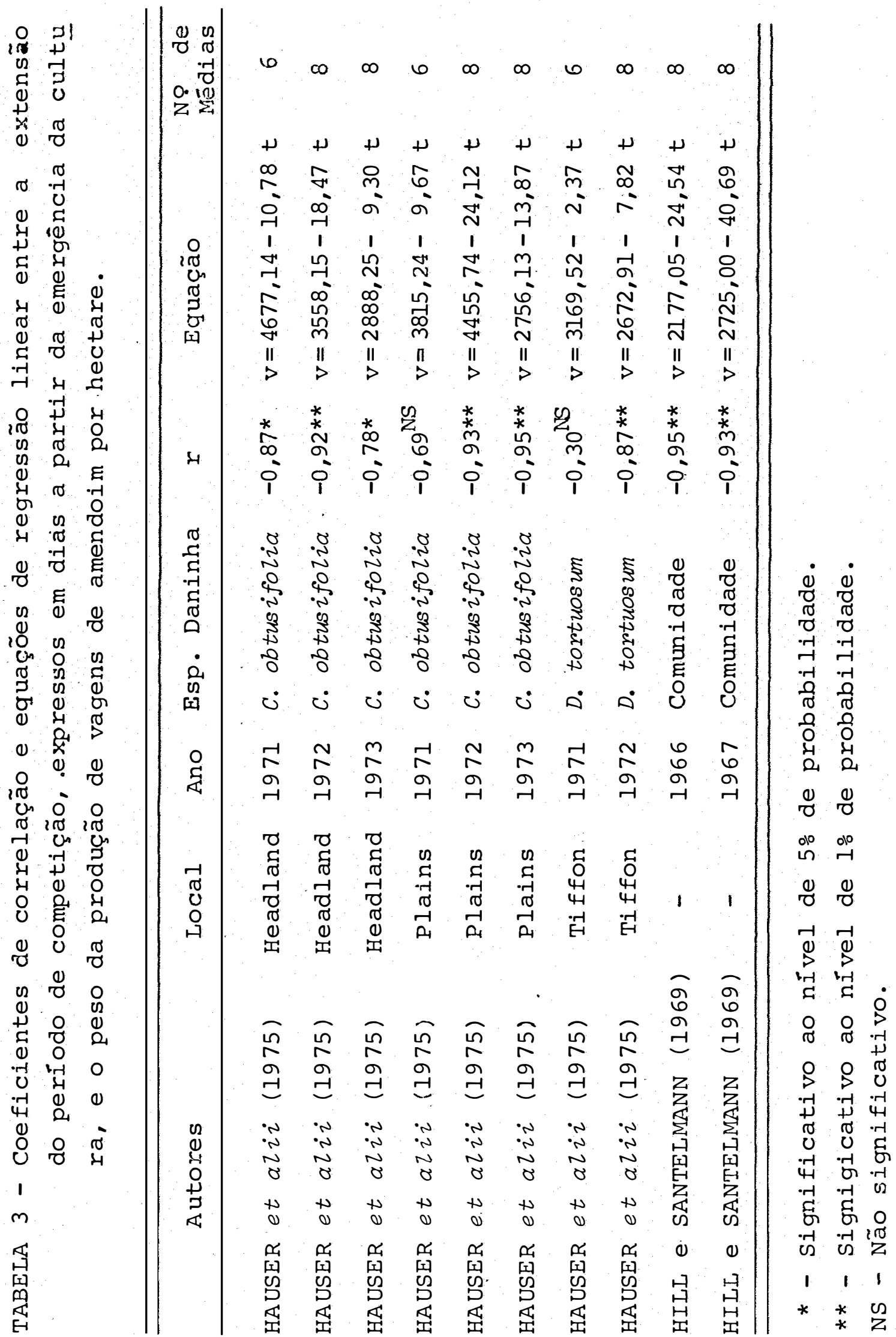


Ihos não existem dados suficientes que permitam correlacionar os valeres de $\underline{r}$ e do coeficiente angular ao grau de infesta ção das plantas daninhas. E de se esperar que em elevadas in festações de plantas danịnhas ou na presença de espécies altą mente competitivas, a manifestação da correlação seja mais in tensa e os valores do coeficiente angular sejam maiores. mesmo comentārio é válido para estações de crescimento em que as condições não sejam muito favoráveis à cultura.

Deve-se entretanto destacar, que comparando os presentes resultados com os de HILL e SANTELMANN (1969) que trabalham com comunidades daninhas, os coeficientes angulares aqui obtidos são menores, indicando uma menor influência do tempo de competição sobre a produtividade da cultura. Entre tanto, os dados disponíveis não são suficientes para tentarse uma explicação razoável do fato.

Outro aspecto a ser observado neste grupo de tratamentos è o período mínimo de convivência múltipla cultu ra-mato, de maneira que a produção não seja alterada signifi cativamente. Pode-se observar que um período de competição acima do 50 dias torna-se crítico à produção da cultura. Quan do se compara a média das produções obtidas nos tratamentos com períodos no mato inferiores à 50 dias com a média de pe ríodos iguajs ou superiores a este valor, observa-se uma di fe rença de produção em torno de 22,5\%, somente suplantado pela comparação entre à média do tratamento mantido no mato por 100 dias e a média dos demais tratamentos, sendo que naquele tratamento houve uma parcela de produção baixíssima, devido 
intensa infestação de Brachiaria plantaginea.

Este valor situa-se no limite superior da fai xa de valores encontrados na literatura e é devicio ao traba Iho de BUNTING e LEA (195.7). Valores superiores à este somen te foram encontrados por HAUSER et alii (1975), estudando com petição de plantas de amendoim com apenas uma espécie daninha, Cassia obtusifolia. Em estudo de competição com comunidades infestantes, os valores sempre foram inferiores.

RODRIGUEZ MARQUINA et aiii (1974) justificam que ao redor de 60 dias após a semeadura, completa-se a maior parte do florescimento da cultura. 'A partir de então a compe tiçaõ torna-se mais crítica, concordando, em parte, com os re sultados do presente trabalho e com a observação de YORK e COBLE (1977) de que a grande interferência das plantas dani nhas se manifesta na formação de vagem e enchimento das semen tes. BIANCO (1978) praticamente confirma esta afirmação de monstrando que a competição influiu sensivelmente na formação das sementes de amendoim, aumentando a porcentagem de semen tes mal granadas e diminuindo a participação de sementes per feitamente granadas.

E interessante considerar que, praticamente, es te é o período em que os recursos do meío começam a sex limi tados e a competição se instala. Este ponto depende de inúme xos fatores como a habilidade dos competidores em recrutar os recursos do meio, a própria abundância do meio em recursos, as condições de desenvolvimento e a própria abundância dos elementos envolvidos na competição e muitos outros fatores. 
Isto justifica os resultados diversos encontrados na biblio grafia, devendo-se destacar que inclusive na maioria das ve zes, as cultivares de amendoim utilizadas foram diferentes.

Analisando-se o grupo de parcelas que tiveram um período inicial no limpo, pode-se observar que as parcelas mantidas no mato durante todo o ciclo apresentaram produções menores do que aquelas que receberam um controle inicial do mato, mesmo que fosse por apenas 10 dias. Comparando a produ ção média do tratamento no mato com a média daqueles que rece beram um controle inicial, independente do período, observa se um decréscimo de produção ao redor de $23,7 \%$ para o primeí ro.

O comprimento do período no limpo não influen ciou significativamente o peso da produção de vagens. O fato leva a crer num período total de competição abaixo de 10 dias. Estè resultado, embora discorde com a quase totalidade da bi bliografia estrangeira consultada, (ORAM, 1961; BHAN et alii, 1971, HILL e SANTELMANN, 1969; FEAKIN, 1973; RODRIGUEZ MARQUI NA et alii, 1974; HAUSER et alii, 1975; RETHINAM et ali , 1976; BUCHANAM et alii, 1966 e YORK e COBLE, 1977), está de acordo com o único trabalho deste tipo encontrado na biblio grafia nacional. Neste, PACHECO (1977) verificou que parce las de amendoim mantidas no limpo por 5 dias, apōs a emergên cia de cultura, não diferiram, em termos de produção de va gens, das parcelas mantidas no limpo durante todo o ciclo" su gerindo um período total de competição inferior à 5 dias. Em razão do exposto, suspeita-se que para nos 
sas condições (cultivar, soìo, comunidade infestante e outros) a generalização feita por yoRK e COBIsE (1977), de que o amen doim é bem menos competitivo que outcas culturas, e portanto mais susceptível à presença das plantas daninhas, não é váli da, uma vez que os níveis de infestação de plıantas daninhas foram relativamente altos e as espêcies predominantes são am plamente citadas na bibljografia nacional e estrangeira como de ocorrência generalizada nesta e em outras culturas comer ciais. Isto também pode ser evidenciado no caso do período inicial no mato em que foram necessārios mais de 50 dias para que a competição, em relação à cultủra, se efetuasse em ter mos de produção de vagens.

O controle inicial das plantas daninhas permi te à cultura uma certa vantágem que a habilitará para melho res condições de competição. BHAN et alii (1971) verifica ram que $75 \%$ dos componentes de uma comunidade infestante eme gem durante os primeiros 30 dias do ciclo de desenvolvimento da cultura do amendoim. Um controle durante este período eli mina, em termos de número de indivíduos, 75\% dos competidores, embora, em termos de biomassa, geralmente este fato não seja verdadeiro, pois os elementos sobreviventes terão maiores quan tidades de recursos à sua disposição para o crescimento.

Após um período inicial no limpo, a própria cul tura, atravës do sombreamento, controla o crescimento das plantas daninhas. BUCHANAM et ali $(1976)$ verificaram "que, independente da extensão do período no limpo, a presença das plantas de amendoim sempre decresceu o crescimento de Cassia 
obtusifolia. HAUSER et alii (1975) observaram que plantas de Cassia obtusifolia que haviam germinado após a $4^{a}$ semana do ciclo da cultura, geralmente não conseguiram desenvolver-se, de modo a emergirem sobre a folhagem da cultura.

Näo foi verificada correlação significativa en tre a extensão do período no limpo e a produção de vagens $\left(r=0,53^{\mathrm{NS}}\right)$. Esta correlação poderia ocorrer até a momento em que o período total de competição fosse atingido. A par tir de então, a cultura passa a apresentar produções simila res à testemunha capinada, independente do período de contro le do mato, diminuindo o. coeficientè de regressão linear. Es te comentário concorda com as correlações calculadas em dados contidos em HAUSER et alii (1975) e HILL e SANTELMANN (1969) e apresentadas na Tabela 4. A única significância foi encon trada no experimento conduzido em Headland no ano de 1971, sen do justamente este o único experimento em que o período total de competição atingiu uma idade mais avançada do ciclo de de senvolvimento da cultura. Esta mesma observação pode ser vá lida quando se comparam os dados destes autores com os de HILL e SANTELMANN (1969) em que os períodos totais de competi ção atingiram o penúltimo e antepenúltimo períodos considera dos, respectivamente em 1966 e 1967.

Não se observou também correlação significatí va entre o comprimento do período no limpo e peso da matëria seca acumulada pelas plantas daninhas por ocasião da colheita da cultura $\left(r=0,55^{\mathrm{NS}}\right)$, indicardo que com 0 desenvolvimento da cultura, o acúmulo da matéria seca pela comunidade infes 


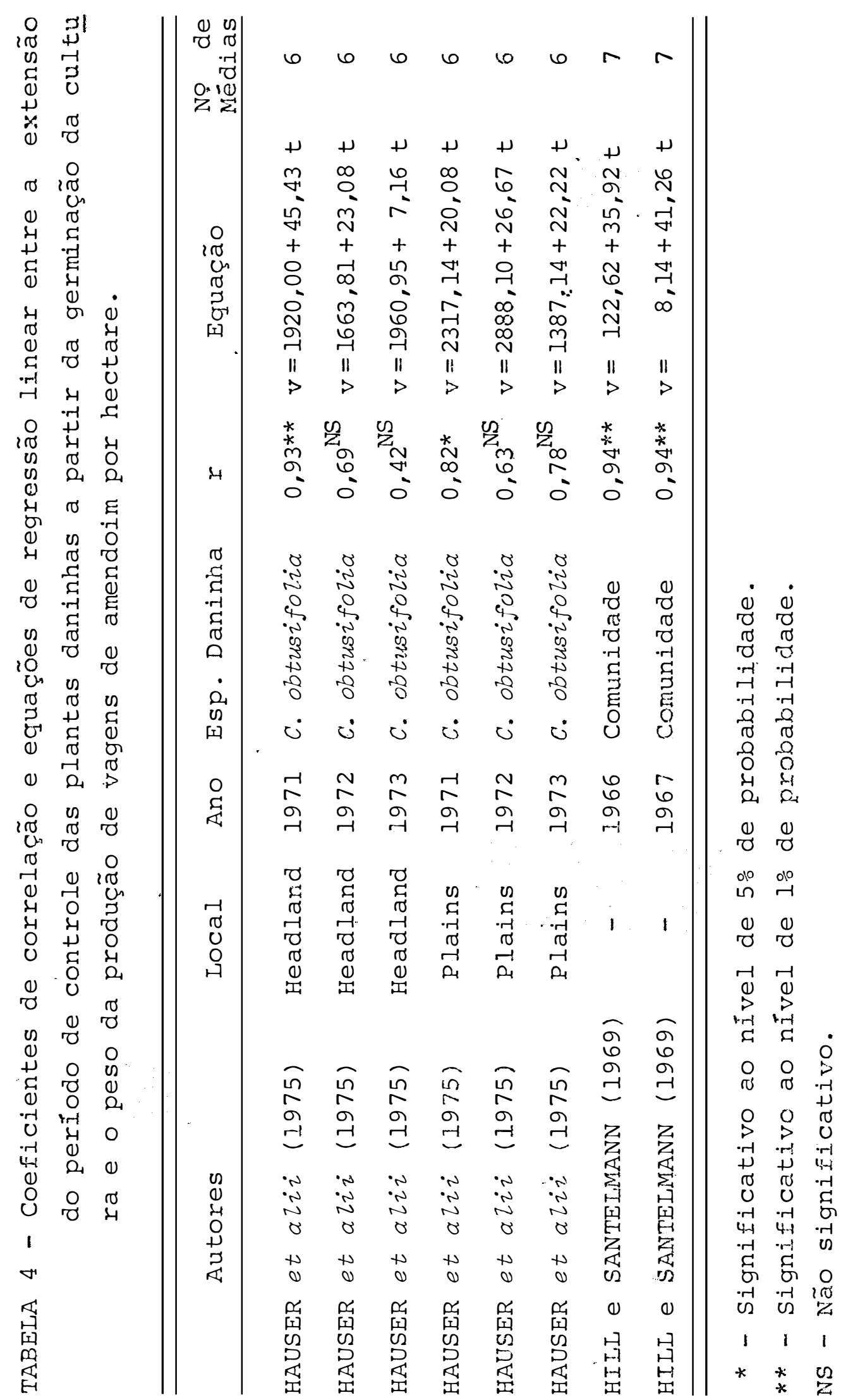


tante independe do tempo disponível ao crescimento, sendo que este ültimo estava limitado principalmente pelo sombrea mento da folhagem do amendoim.

Dependendo das condições locais, muitas vezes é interessante prolongar as capinas por períodos maiores que o período total de competição, a fim de evitar-se a interfe rência das plantas daninhas nas operações de colheita e seca gem dos frutos no campo (HILL e SANTELMANN, 1969; DRENNAM e JENNINGS, 1977 ) .

DRENNAM e JENNINGS (1977) consideram que quan do a perda de produção de vagens da cultura do amendojm atin ge 50\% ocorre um equilíbrio entre a cultura e a comunidade in festante, em termos de competição. Existe, na bibliografia corsultada, valores de decréscimos de produção, devidos à ma to-competição, variando desde 12\% (LEVI, i975) até (DRENNAM e JENNINGS, 1977). O maior decréscimo de produção observado na presente pesquisa foi verificado quando compa rou-se o grupo de parcelas com períodos no mato inferiores à 60 dias com aquele com períodos superiores à 70 dias, sendo de $25,9 \%$ Outros resultados obtidos na mesma localidade e so lo não diferem muito, à saber, 35\% (SADER, 1975) e 12\% (LEVI, 1975), excessão feita a BIANCo (1978) que encontrou um decxés cimo de produção ao redor de 63\%. Este último autor traba lhou com a "cultura da seca" numa época em que a deficiência hídrica foi acentuada. Sabe-se que em condições desfavorávæi.s de umidade a cultura sofre mais intensamente os efeitos da competição (DRENNAM e JENNINGS, 1977; FEAKIN, 1973). 
De uma maneira geral, nos trabalhos consulta dos, os pesquisaciores se preocupam, ãs vezes, exclusivamente com o peso da produção de vagens, sendo portanto este o único parâmetro com dados suficientes parà uma comparação mais acu u rada dos resultados orà obtidos. E claro que as condições de desenvolvimento das outras pesquisas foram totalmente diferen tes, inclusive quase todos os autores trabalharam com cultiva res diferentes. Entretanto, na presente pesquisa e na biblio grafia nacional consultada, exceção feita a BIANCO (1978) po de-se verificar que os efeitos da competição sobre a produção de vagens foram baixos ẹm rèlação à literatura estrangeira. Este fato pode ser explicado pela alta competitividade das cultivares utilizadas nos trabalhos ('Tatü -53 '. em todos os casos), ou pelas condições regionais que favorecem a cultura em relação a comunidade infestante, uma vez que as espécies predominantes são fartamente citadas na bibliografia como pro blemática à esta e outras culturas no Brasil e no mundo (BLAN co, 1978). A ocorrência dos dois. fatos tambëm é possível.

Outro aspecto que deve ser destacado é que exa minando a Figura 2, o final do primeiro período no limpo (10 dias) aconteceu numa época, em que não chovia a 0.4 dias. Nes te dia foi feita uma ültima e rigorosa coleta de plantas dani nhas destas parcelas. Daí por diante, houve três pequenas precipitações $(0,5 ; 3,1$ e $2,1 \mathrm{~mm})$ e a posterior precipitação de destaque somente ocorreu já no final do segundo período no limpo. Supõe-se que nesta época, de alta temperatura e in solação (acima de 8 horas đe sol por dia, em média), com o so 
lo descoberto, houve uma rāpida evaporação dá água da camacia superficial do solo, sendo que as precipitações pequenas ocor ridas foram menores que a taxa médja de evapotranspiração diâa ria de nossa região $(4 \mathrm{~mm} / \mathrm{dia})$. Estas condições devem ter in fluenciado negativamente na germinação das plantas daninhas. Com a cultura já germinada e o sistema radicular atingindo pro fundidades com alto teor de umidade, uma vez que, anterior a este período ora discutido as precipitações foram abundantes, houve um favorecimento das conăições em relação à cultura.

Quando as chuvas voltaram a ser suficientes, jä ocorria um de senvolvimento maior da cultura, tendo esta uma maior capacida de competitiva, principalmente atravës do sombreamento.

Uma vez que a porcentagem de casca não foi al terada significativamente pela competição das plantas dani nhas, espera-se que o peso da produção de sementes por uni da de de ärea seja afetada de maneira similar a produção de vạ gens por parcela. Este fato realmente ocorreu como pode-se verificar pelos resultados da anälise de variância e teste de Tukey. Não se verificou correlação direta entre o peso dă produção de sementes por unidade de ärea e a extensão do pe ríodo no limpo. Esta correlação existiu no caso dả extensão do período no mato $(r=0,81 * *, s=531,29-1,78 t$, onde $\mathrm{s} e$ o peso da proaução de sementes por parcela), indicando que o peso da produção de sementes decresce proporcionalmente ao tempo em que a cultura permanece no mato, a partic da germina ção. E interessante ressaltar que comparando o coeficiente angular desta equação com aquele da produção de vagens por 
parcela, verifica-se que a produção de sementes é levemente menos sensỉvel à competição. Tal fato seria lógico se a por centagem de casca também fosse negativamente afetada, o que jā è citado na bibliografia (ISHAG, 1971; BUCHANAM et a $i$ i , 1976.; BIANCO, 1978 ).

Na comparação entre a média das parcelas com períodos iniciais no mato inferior a 50 dias com aquela das parcelas com períodos superiores ou iquais a 60 dias, obsex va-se um decréscimo de produção de vagerıs ao redor de $26,0 \%$, enquanto que no caso da produção de sementes este valor foi de 22,0\% indicando que tambëm a porcentagem de casca havia sido alterada. O valor médio de porcentagem de casca do pri meiro grupo de tratamentos foi 28,5\%; ao passo que no segundo grupo foi $27,6 \%$. BIZNCO (1978) observa que o decréscimo na porcentagem de casca não é simplesmente o reflexo do inverso do crescimento das sementes no seu interiox, mas que a pró pria casca é afetada na sua formação. É possível que pela Ii mitação dos recursos do meio, principalmente de luz, através do sombreamento, ocorra uma diminuição na quantidade de fotos sintetizados e na sua translocação, diminuindo, portanto o acúmulo de celulose e hemicelulose na casca.

A anälise de regressão mültipla com os três pâ râmetros da tabela, como era de se esperar, foi altamente sig nificativa $\left(R^{2}=0,99 * *\right)$. Pela equação $v=-211,38+1,42 c+$ $+7,07$ s, onde $\underline{E} \ddot{e}$ a porcentagem de casca, pode-se verificar que a produção de sementes foi o mais importante fator na de terminação da produção de vagens. De.fato estes dois parâme 
tros foram altamente correlacionados $(r=0,99 *, v=2.3,39+$ $+0,68 \mathrm{~s})$. Não houve correlação entre a produção de vagens ou de sementes e a porcentagem de casca.

Os roeficientes angulares e a significância das regressões lineares simples nos diferentes intervalos de t.ra tamentos com período inicial no mato estão apresentados na Figura 6 .

Não se verificou correlação linear dentro de qualquer dos intervalos de período no mato considerados e a porcentagem de casca do amendoim. Com relação as produções de sementes e de vagens por parcela, os resultados obtidos fo ram similares. Em ambos os casos, a medida que tratamentos com maiores períodos no mato, passam a ter maior participaçäo no cälculo da média dos intervalos, estas ültimas decrescem, evidenciando os efeitos do tempo de competição sobre a mani festação destes parâmetros.

A curva determinada pela média dos intervalos parece ser levemente mais inclinada no caso da produção de vá gens. Tal fato, poderia ser uma evidência de que a porcenta gem de casca teria sido alterada negativamente pela mato-com petição. Com os dados das médias dos intervalos de ambos os parâmetros (y), utilizando-se o valor mínimo de cada interva lo como uma série comum em ambos os parâmetros $(x)$, estabele ceu-se estudo de correlação linear, sendo significativo nos dois casos $(r=0,98 * *$, em ambos os casos $)$. Realmente, o coe ficiente angular foi mais negativo para a prociução de vagens $(b=-15,70)$ em relação a produção de sementes $(b=-10,75)$. 
53.

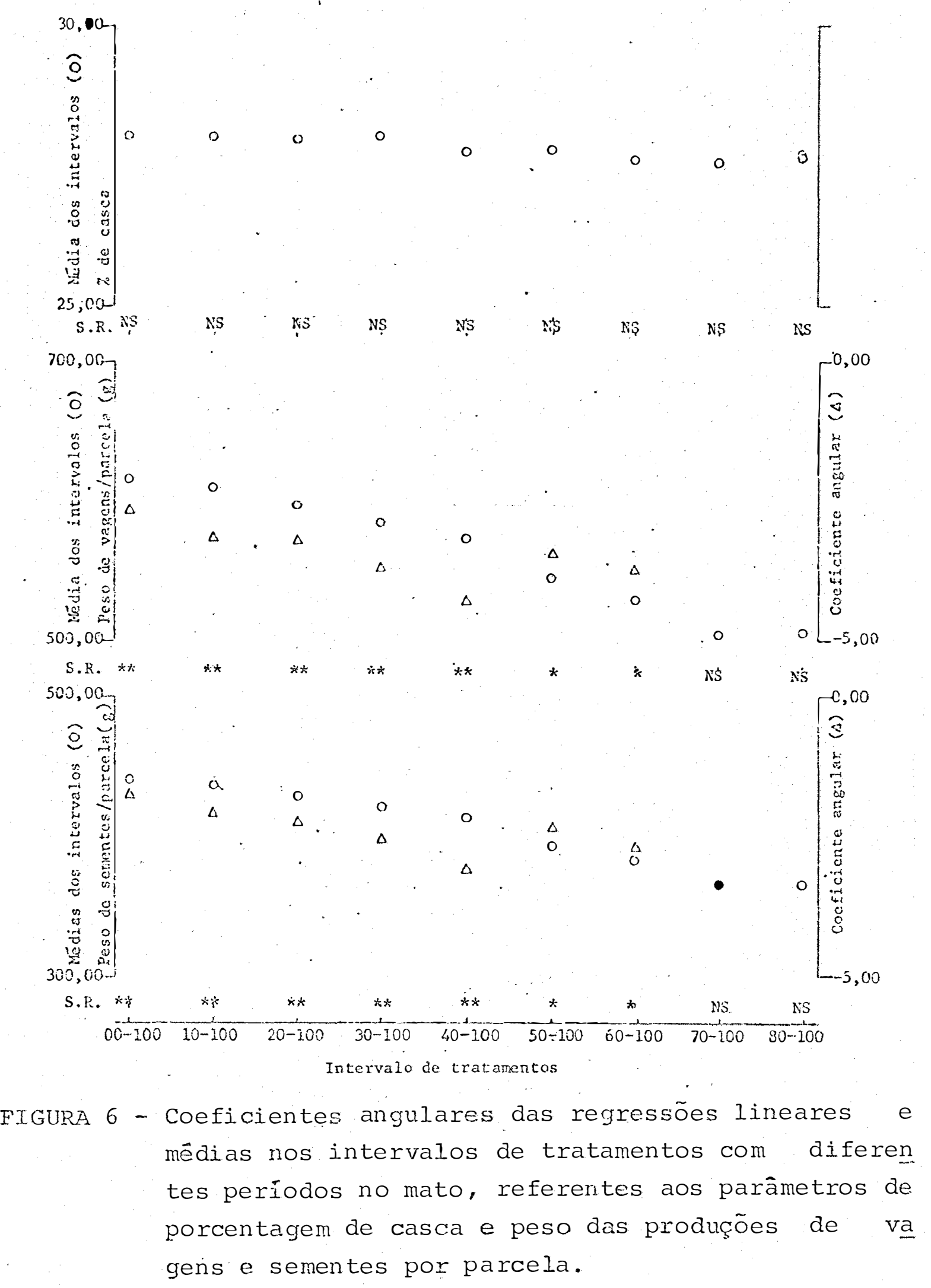


Contudo, a diferença de inclinação destas duas curvas nao foi significativa $\left(t=0,68^{\mathrm{NS}}\right.$, conforme STEEL e TONIE, 1972).

Também, em ambos os parâmetros, os coeficien

tes angulares foram decrescendo gradativamente, até quando se considerou o intervalo de tratamentos desde 40 até 100 dias no mato. A partir daí, considerando-se apenas intervalos maio res que 40 dias, quando a regressão foi significativa, os coe ficientes angulares foram maiores ao intervalo supracitado.

Pelo exame dos dados contidos na Tabela 2 e os dos coecifien tes angulares ora discutidos, pode-se supor que no tratamento com 40 dias no mato, a produção ainda foi similar a testemu nha (0 dias no mato). Menores períodos no mato produziam simi larmente à este tratamento e, com isso, o coeficiente angular foi menos pronunciado. Considerando-se apenas periodos maio res que 40 dias; os valores do coeficiente angular passam a depender de outros parâmetros, principalmente composição espe cífica e grau de infestação do mato, uma vez que a competição já está estabelecida.

Estes resultados parecem reforçar a observação de que un período em torno de 50 dias no mato, a partir da emergência, torna-se crítico a esta cultura.

O peso da produção de vagens e ảe sementes por unidade de ārea é função do "stand" da cultura e dos pesos das produções de vagens e de sementes por indivíduo, respectí vamente. Estes últimos parâmetros esțão apreséntados na Tabe la 5 .

Não se verificou efeitos ãa competição

das 


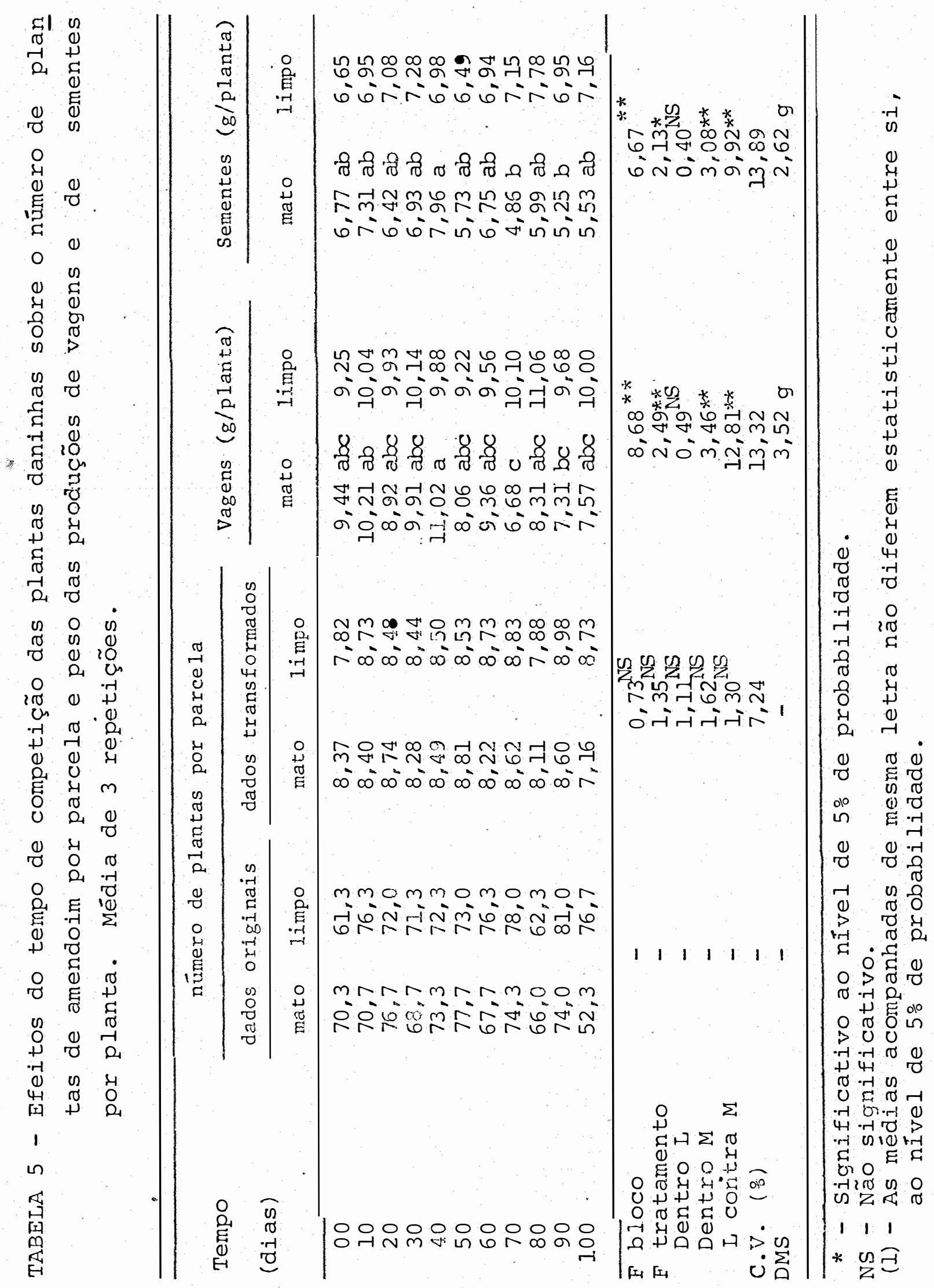


plantas daninhas sobre a sobrevivência das pilantas de amen doim, muito embora quando se compara parcelas que não recebe ram nenhuma capina com aquelas que tiveram um período inicial no limpo, independente cảa extensão deste, observa-se um "stand" 17\% menor. Inclusive, não houve qualquer correlação entre o comprimento do período no lịmpo ou no mato com o "stand" da cultura. Já è conhecido na bibliografia o fato de que a competição altera em maior proporção a produtividade por indivíduo do que a próprìa sobrevivência das plantas (BIANCO, 1978). HAMDOUM (1977) observou um decréscimo da prọ dução de vagens de amendoim da oxdem de $73 \%$, enquanto que o "stand" da cultura decresceu apenas $24 \%$ O decréscimo de pro dução por indivíduo foi da ordem de 55\%.

Não tendo sido o "stand" da cultura afetado sigg nificativamente pela competição, espera-se que os efeitos do mato sobre as produções por indivíduo apresentem aproximadą mente as mesmas tendências observadas para as produções por unidade de área. Com efeito, em ambos os parâmetros (vagens e sementes), os tratamentos diferiram significativamente en tre si e o desdobramento dos graus de liberdade mostrou que o grupo de parcelas com periodos iniciais no limpo produziu sig nificativamente mais que aquele com períodos iniciais no mato; alêm disso, acusou a existência de contrastes significativos dentro de grupo de tratamentos com períodos iniciais no mato. Em ambos os casos verificou-se correlações signi ficativas entre as extensões dos períodos no mato e as produ ६̧̃̃es de vagens $\left(r=0,70 *, v_{i}=201,88-17,26 t\right.$, onde $v_{i}$ é o 
peso da produção de vagens por indivíduos) e de sementes por indivíauo $\left(r=0,68 *, s_{i}=201,40-23,96 t\right.$, onde $\underline{s_{i}}$ é 0 peso da produção de sementes por indivíduol. Como à seguir procul rar-se-á estudar mais detalhadamente a produção dẹ sementes de uma maneira mais qualitativa, procurou-se uma regressão müI tipla entre as produções de sementes por unidade de áreà, por indivíduo e "stand" da cultura, sendo esta altamente signifi cativa $\left(R^{2}=0,88 * *\right)$. A equação encontrada foi $s=30,11+$ $+66,44 \mathrm{si}-0,22 \mathrm{n}$, onde $\underline{\mathrm{n}}$ é o número médio de plantas por parcela. Pela equação pode-se verificar que o principal fá tor determinando a produtividade de sementes por unidade. de área foi a produtividade por indivíduo. Estranho é a influên cia negativa do "stand". Provavelmente isto está ligado ao fato de que, embora não significativa, o coeficiente de corre lação entre o "stand" e a produtividade por indivíduo foi mais negativa que entre aquele parâmetro e a produtividade por parcela, sendo que o efeito do aumento do "stand"e, é claro, aumento do número de indivíauos sobre a mesma quantidade de recursos do meio, foi mais intenso sobre a produtividade por individuo do que o aumento que um nümero de plantas pode de terminar na produção por unidade de ärea.

Na Figura 7 pode-se observar que o "stand" foi levemente influenciado pela competição, pois à medida que os tratamentos com maiores períodos no mato tiveram maior parti cipação no cälcuıo das médias, estas ültimas diminuiram leve mente. Observa-se que alguns contrastes entre médias foram significativos enquanto que outros não, e que a significância 

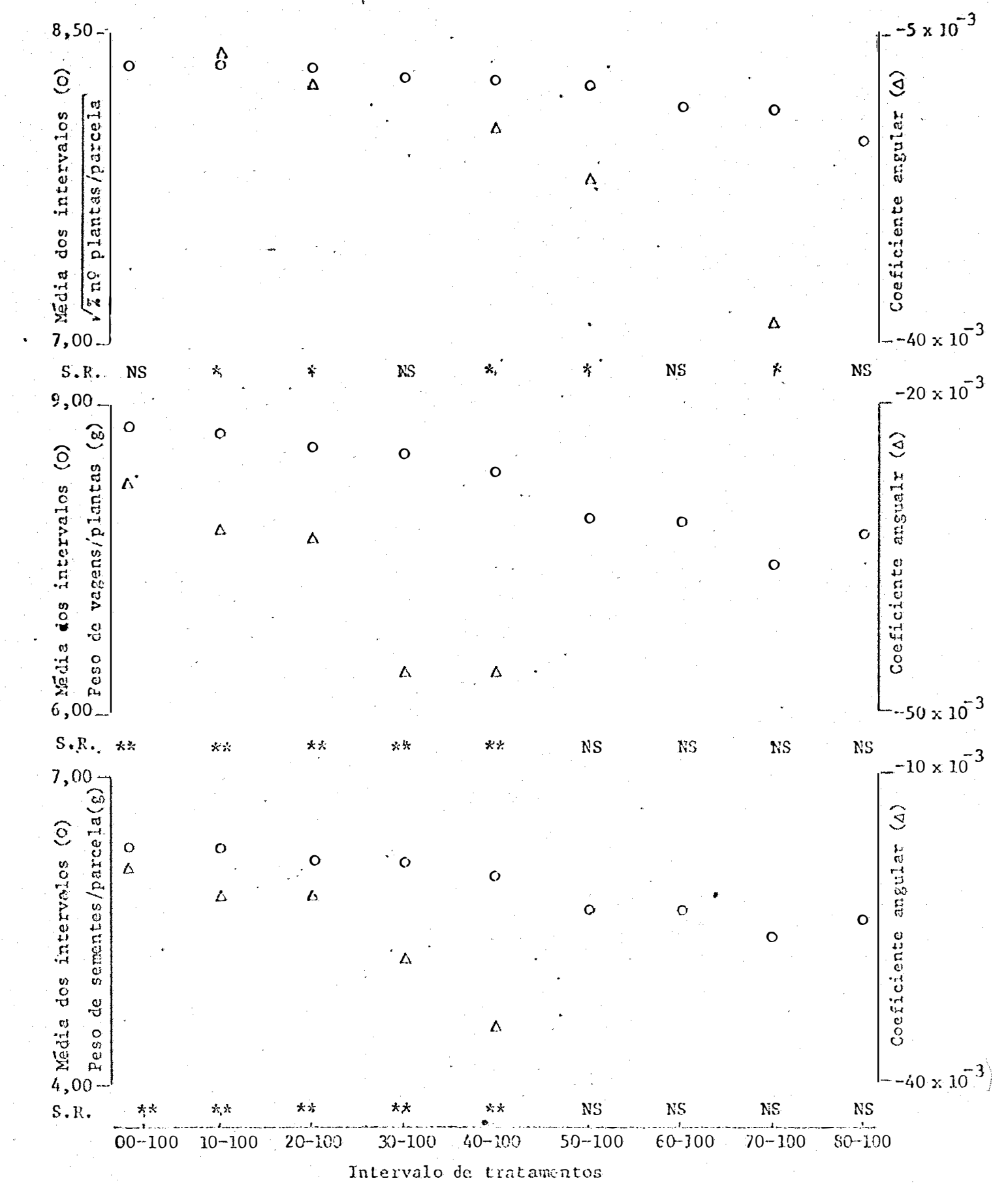

FIGURA 7 - Coeficientes angulares das regxessões lineares e médias dos intervalos dos tratamentos com diferen tes períodos no mato, referentes aos parâmetros de "stand" da cultura e pesos das produções de vagens e de sementes por planta. 
foi alternada e não ob̉edeceu um padrão definido. Isto parece ser mais uma prova de que houve uma leve tendência, embora não definida, do efeito do mato sobre a sobrevivência das plantas de amendoim.

A exemplo do que ocorreu.nas produções por par cela, tanto a produção de sementes quanto de vagens por indi víduo, tiveram o maior decréscimo dos valores das médias quan do se considerou apenas períodos no mato superiores à 50 dias. Tambēm, apenas quando se incorporou períodos no mato inferio res ou iguais à 40 dias no contrastes é que estes foram signi ficativos, e à medida que os períodos no mato menores eram in corporados, os valores dos coeficientes angulares baixavam consideravelmente. Este fato também indica que 40. dias no mato as parcelas ainda apresentavam produçöes por planta iguais à testemunha, dando então o maior coeficiente angular de correlação. Períodos menores produziram simillarmente à es te ültimo valor e, com isso, menós médias estavam correla cionadas ćom o tempo no mato. Com isso, os cocficientes angu lares diminuiram.

A produção de sementes por indiviauo, pos sua vez, é função do peso médio das sementes, do nümero mëdio de sementes por vagem e do número médio de vagens por planta. Es tes dados estão apresentados na Tabela 6 .

o nümero médio de sementes por vagem não foi alterado significativamente pela competição imposta pelas plantas daninhas. Sabe-se que esta é uria caracterïstica va rietal, sendo que para a cultivar utilizada este valor situa- 


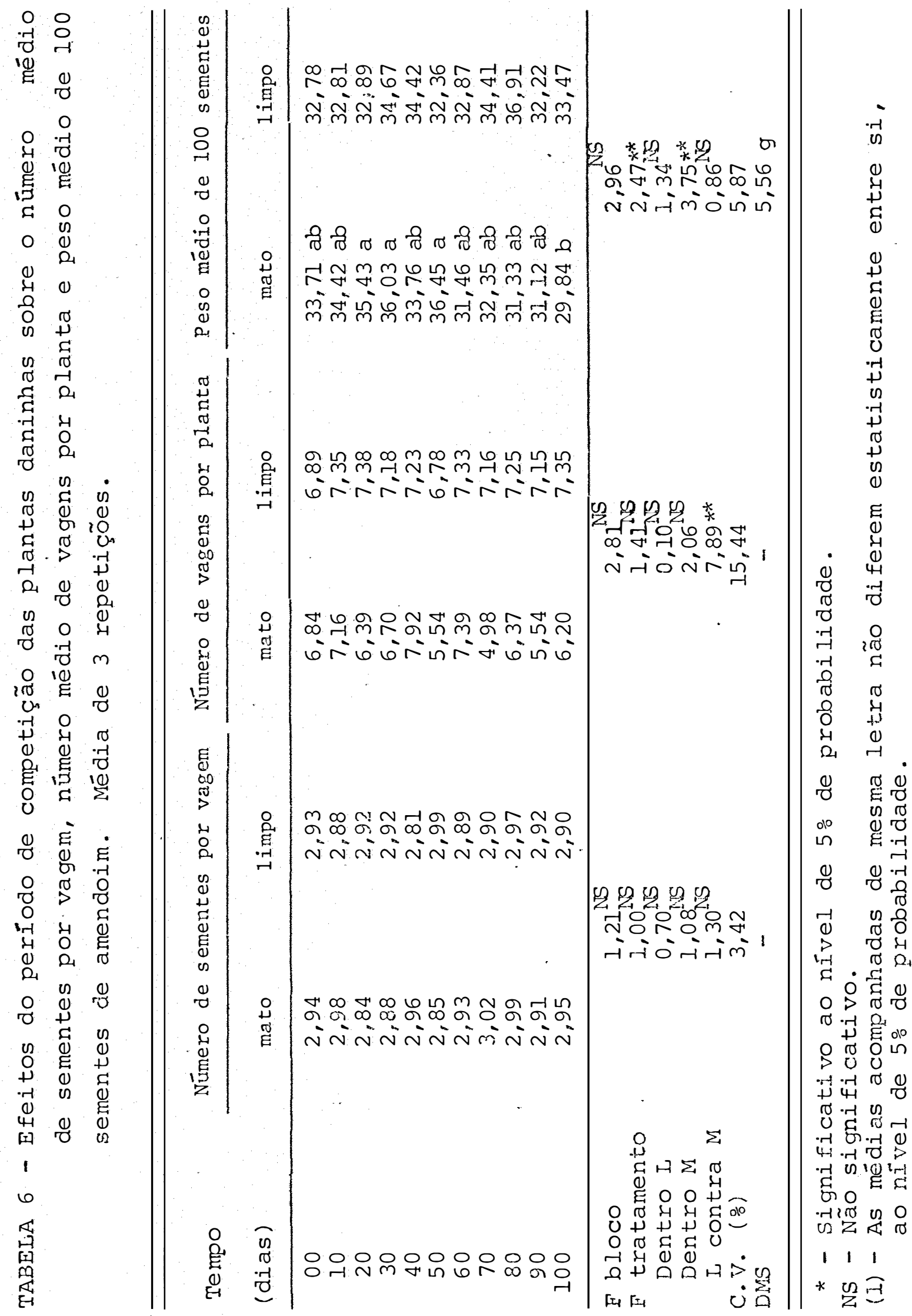


se ao redor de 3,14 (Sichmann, 1961, citado por SICHMANN e LASCA, 1973). Os valores ora observados são levemente infe riores àqueles citados, talvez devido ao fato de que não foi feita amostragem para este tipo de determinação e sim avalia das todas as vagens de cada parcela experimental, inclusive aquelas que não possuiam sementes no seu interior.

Sendo esta uma característica varietal, a úni ca possibilidade da competição alterar a expressão deste parâ metro, seria atravês da alteração do nümero de sementes abor tadas. ISHAG (1971) verificou, em amendoim, que o maior efei to da competição das plantas daninhas foi sobre o enchimento das sementes e não sobre a viabilidade dos óvulos: BIANCO (1978), trabalhando com esta mesma cultivar, não encontrou qualquer efeito da competição sobre a proporção de sementes abortadas e, conseqüentemente, sobre o númexo de sementes por vagèm.

HAMMERTONN (1976) acredita que um dos princi pais efeitos da competição das plantas daninhas é expresso só bre o florescimento e que este efeito pode alterar o nūmero de sementes por vagem. ISHAG (1971) observou que a presença das plantas daninhas provoca uma certa desuniformidade no flo rescimento da cultura do amendoim. Acredita-se que devido a desuniformidade no desenvolvimento e na distribuição das espẹ cies daninhas na área da cultura, as plantas de amendoim es tarão sujeitas às mais diversas condições de sombreamento, de variações térmicas e hỉdricas dó ar e do solo, competição por nutrientes, de liberação de exudatos radiculares e outros fa 
tores que poderiam, direta ou indiretamente, alterar o flores cimento. Assim, com desuniformjdade de florescimento e, con seqüentemente, de Erutificação, por ocasião da colheita, en contrar-se-ão vagens aj.nda, em processo de formação. Com isso, pode. ocorrer, um aumento na proporção de vagens com 1 ou 2 se mentes quando colhe-se uma parcela no mato ao lado de uma par cela no limpo, explicando, em parte, os resultados observados por HAMMERTOON (1976). E claro que este efeito depende de muitos fatores como a susceptibilidade da cultivar de amen doim, a composição específica do mato, condições climäticas e outras. Para nossas condições não houve qualquer efeito so bre a distribuição porcentual de vagens com diferentes tama nhos, como pode ser observado na Tabela 7.

Ainda na Tabela 6 pode-.se observar que o núme ro de vagens por planta foi alterado significativamente pela competição, acusado apenas no desdobramento dos graus de li berdade dos tratamentos. O grupo de tratamentos com periodo inicial no mato apresentava valores significativamente meno res em relação ao outro grupo de tratamentos. Não se obser vou, qualquer correlação significativa entre as extensões dos períodos no mato ou no limpo e o nünero de vagens por planta de amencoim (valores de $\underline{r}$ de $0,47^{\mathrm{NS}}$ e $0,18^{\mathrm{NS}}$, respectivamen te). ISHAG (2971) havia verificado que em parcelas mantidas no limpo, o nümero de vagens por planta chegava a ser 50\% mais elevado que em parcelas mantidas em cornpetição•com as plantas daninhas. Para o autor, o número de vagens por planta foi o principal fator da queda da produtividade da cultura, devida 


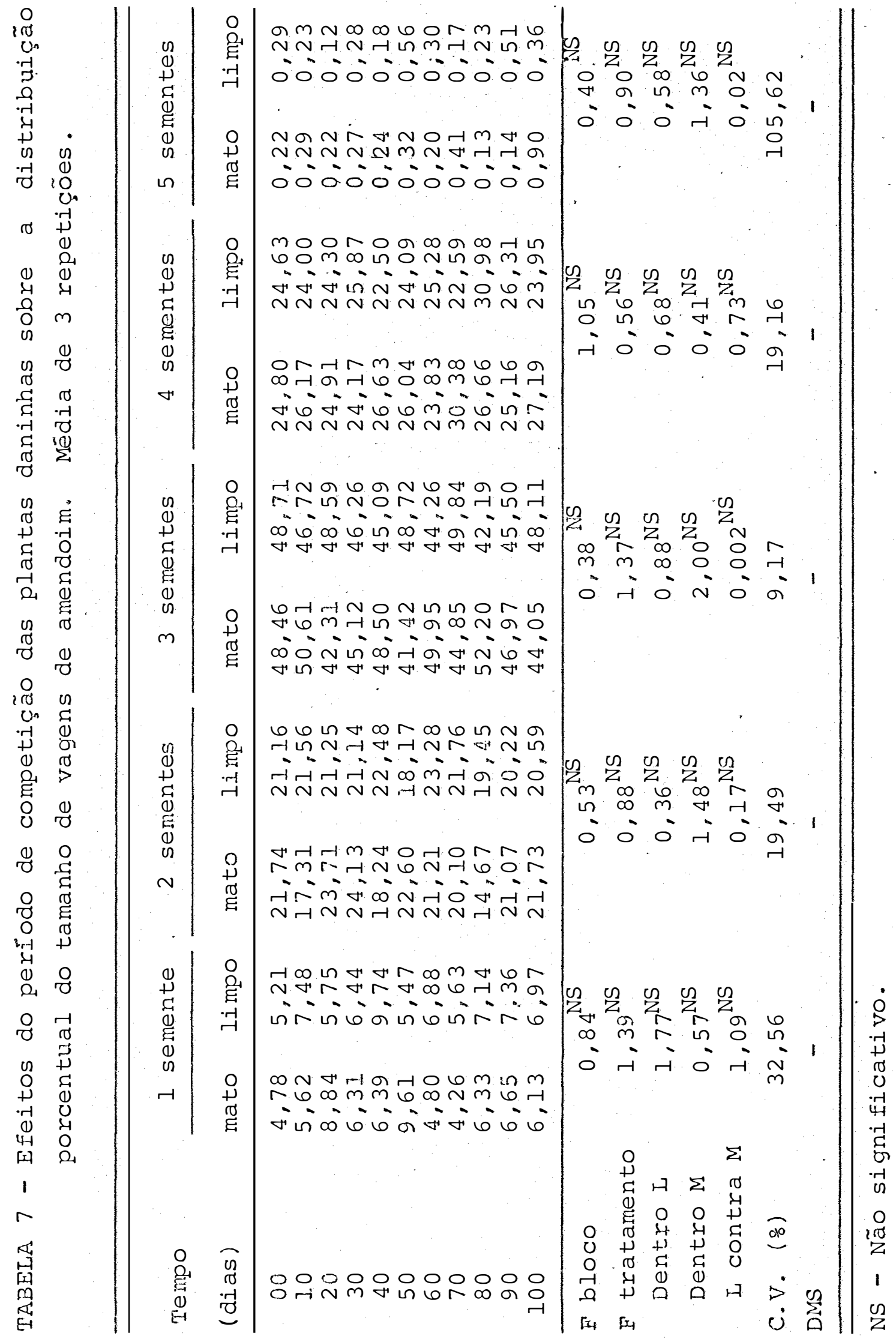


a competição do mato. Encontrou ainda que o nümero de vagens por planta estava altamente correlacionada ao nümero de ramos e. ao nümero de flores por planta, sendo que este ültimo, tam bém, foi função do penūltimo. BIANCO (1978) observou uma re dução mëdia de $56,3 \%$ do número de vagens por planta devila a competição das plantas daninhas ratificando, em parte, as con clusões de ISHAG (1971), uma vez que encontrou alta correla ção entre este parâmetro e a produçäo de vagens por unidade de ārea $(r=0,98 * *)$. No presente trabalho, esta correlação tam bém foi encontrada no grupo de tratamentos com período ini cial no mato apenas com um menor coeficiente de correlação li near $(r=0,69 *)$. Entretanto, esta correlação foi bastante alta quando se comparou com a produção de vagens por planta $\left(r=0,92 *, v_{i}=1,15+0,60 \mathrm{n}_{\mathrm{v}}\right.$, onde $\underline{\mathrm{n}_{\mathrm{v}}}$ ë o nümero de va gens por planta) e a produção de sementes por planta ( $r=$ $\left.0,94 * *, s_{i}=0,9 I+0,88 \mathrm{n}_{\ddot{v}}\right)$. Sendo que a produção de semen tes por planta foi o fator preponderante da produção de semen tes por unidade de ärea, pode-se sugerir o mesmo tipo de con clusão no presente trabalho, uma vez que não se encontrou cor relação direta entre este parâmetro, e o nümero de sementes por vagem $\left(r=0,06^{N S}\right) e$, também, com relação ao peso médio de 100 sementes $\left(x=0,40^{\mathrm{NS}}\right)$.

O peso médio de 100 sementes, por sua ver, so freu influência significativa da competição das plantas dani nhas. O desdobramento dos graus de liberdade mostrou um peso significativmente maior em parcelas com período inicial no limpo. Além disso, dentro do grupo de tratamento com um pe 
ríodo inicial no mato ocorreram contrastes significativos. A correlação entre a extensão do período inicial no mato e o pe so médio de 100 sementes foi significativa $(r=0,75 * *, p=$ $35,74-0,05 t$, onde $\mathrm{p}$ é o peso médio de 100 sementes), indi cando que o tempo de competição a partir da germinação da cul tura influencia negativamente o acúmulo de matéria em semen tes de amendoim. Tal fato pode estar relacionado à efeitos da competição sobre a translocação de materiais para formação das sementes, à limitação da fotossintese da planta, não ten do material para enchimento das sementes ou à desuniformidade no fflorescimento e/ou frutificação, sendo que na colheita obte ve-se sementes em pleno processo de formação (HAMNERTONN, 1976). BIANCO (1978) observou que a competição das plantas daninhas alterou a granação das sementes de amendoim, diminuindo em 13,9\% a porcentagem de sementes granadas ẹ aú mentando em 40,3\% a porcentagem de sementes mal granadas. ISHAG (1971) verificou que os efejtos da competição foi sobre o enchimento das sementes de amendoim, uma vez que em determi nados tratamentos em que a cultura era mantida livre da compe tição por certo intervalo de tempo, o florescimento era nor mal, mas o peso médio de 100 sementes era diminuído sensivel mente. Tal fato, tambëm foi ressaltado por yORK e COBLE (1977), os quais verificaram um período tardio crítico de com petiçãc de plantas em amendoim, sugerindo efeitos da competi ção sobre a fixação dos frutos e/ou enchimento das sementes.

$$
\text { RODRIGUES MARQUINA et alii (1974) verificaram }
$$
que períodos maiores de 50 dias de convivência múltipla entre 
a cultura do amendoim è a comunidade infestante, promoviam efeitos sensíveis na produção e que este fato estava correla cionado ao período ligeiramente posterior do māximo floresci mento da cultura que ocorria entre 40 e 50 dias, época de for mação dos frutos e sementes. Estes resultados concordam com os verificados no presente trabalho. A média dos tratamentos que tiveram períodos no mato de até 50 dias foi de $34,97 \mathrm{~g}$ por 100 sementes, ao passo que, em períodos maiores no mato, a mécia foi de $31,22 \mathrm{~g}$. Além disso, considerando-se que para nossas condições e para a cultivar utilizada, o período de florescimen to é similar ao encontrado por RODRIGUEZ MARQUINA et alii (1974), estudou-se a correlação entre o tempo de competição an terior aos 60 dias e o peso médio de 100 sementes. O coefí ciente de regressão linear não Eoi singificativo $\left(r=0,56^{N S}\right)$. Contudo, quando o período de competição consjderado foi supe rior ou igual à 60 dias, a correlação foi altamente significạ tiva $(r=0,78 * *, p=34,80-0,045$ t). Isto sugere que rea I mente o período de formação do fruto e da semente é bastante sensível à competição das plantas daninhas. Deve-se esclare cer que, embora a bibliografia consultada não mostre claramen te, tambēm a desuniformidade de florescimento $e$, conseqüente mente, de maturação dos frutos, contribue para o decrëscimo do peso médio das sementes de amendoim submetidas à competição das plantas daninhas.

O peso médio de sementes, é por'sua vez, um reflexo da proporção de sementes de diversos tamanhos. Na Tá bela 8 estão apresentados os resultados referentes à distribui 
ção porcentual, calculada com dados de peso de sementes clas sificadas em peneiras de diferentes diâmetros de crivo, vari ando desde 18 até $22 / 64$ de polegadas.

Pode-se observar que em todos os diâmetros hou ve influência significativa da competição sobre as porcenta gens de sementes. O desdobramento dos graus de liberdade dos tratamentos mostrou, em todos os casos, a existência de con trastes significativos no grupo de tratamentos com período inicial no mato, o que não ocorreu no grupo de tratamento com período inicial no limpo. Não se observou significância dos contrastes comparando os dois grupos de tratamentos, em qual quer diâmetro de crivo. Comparando-se os tratamentos com pe ríodo inicial no mato, que sofreram mais intensamente os efei tos da competição, com aqueles com período inicial no limpo, pode-se verificar a tendência da competição aumentar a porcen tagèm de sementes com diâmetros menores que 19/64 de polegada e diminuir a porcentagem de sementes com diâmetros maiores de 21/64 de polegada, ocorrendo um equilíbrio na peneira 20.

Este tipo de efeito é mais flagrante quando se comparam parcelas com períołos no mato inferiores ou igual à 50 dias com aquelas superiores à este valor, considerado crí tico para o peso médio de 100 sementes. Observa-se, em parce las com períodos no mato superiores a 60 dias, um aumento de $39,1 \%$ na porcentagem de sementes com diâmetros inferiores a 18/64 de polegada, em relação à períodos no mato igual ou in feriores à 50 dias. No caso daśs peneiras 18 e 19, ainda observou-se um efeito positivo da competição sobre a porcenta 
68.

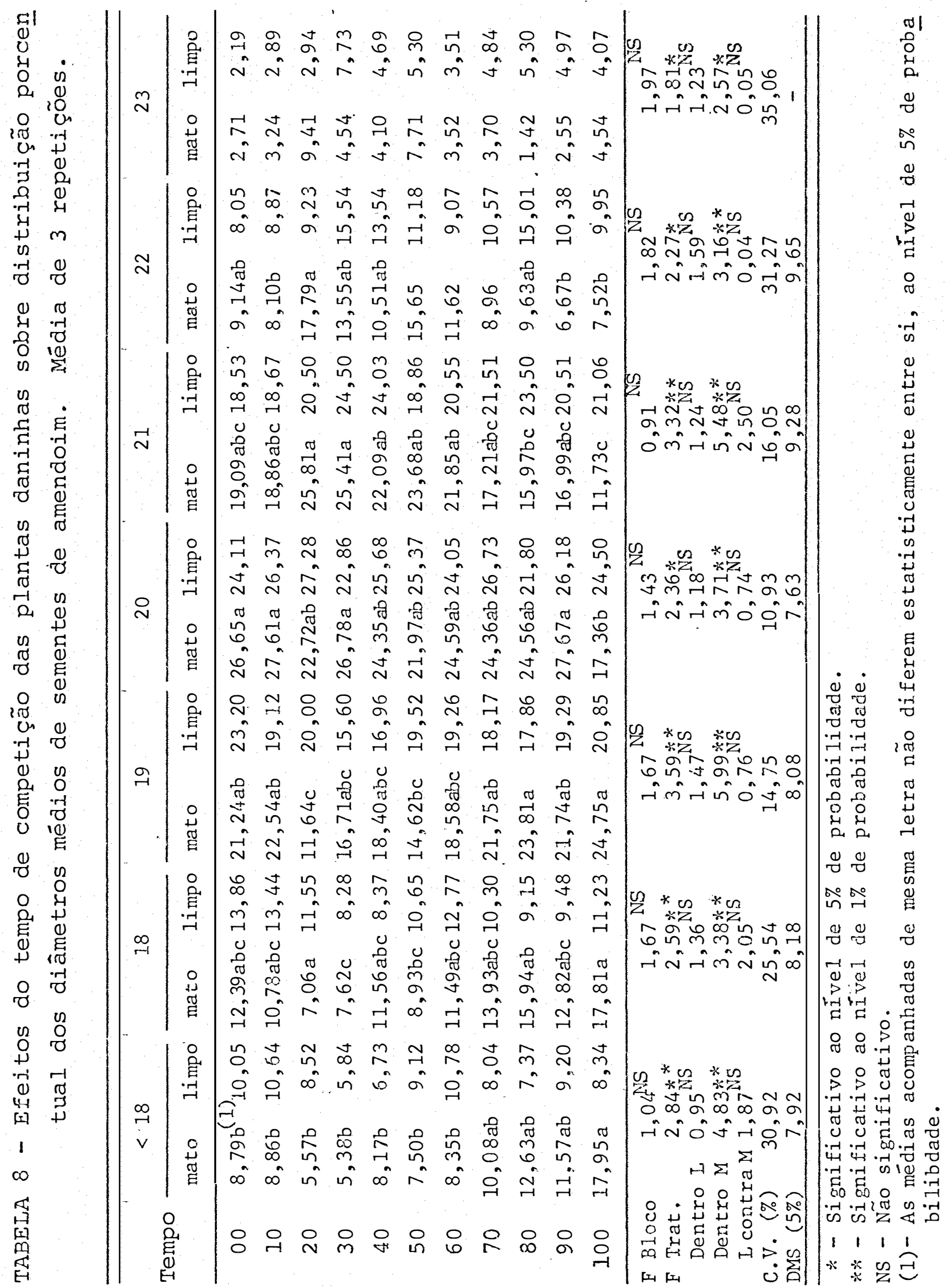


gem de sementes classificadas nestas peneiras de $32,5 \%$ e $20,8 \%$, res pectivamente. Houve um equilíbrio de sementes classificadas na pe neira 20. Em sementes maiores, a competição das plantas dani nhas decresceu as participações de 23,7\%, 28,7\% e 40,3\% no ca so das peneiras 21,22 e maiores de 22, respectivamente. Então, a competição das plantas daninhas altera sobre maneira a dis tribuição de sementes de diferentes diâmetros, aumentando a participação de sementes pequenas e diminuindo a participação de sementes maiores. Com isso, o peso médio de 100 sementes é alterado.

Com efeito, observaram-se correlações negatí vas e significativas entre o peso médio de 100 sementes e a porcentagem de sementes classificadas em peneiras abaixo de 1.8 $\left(r=-0,84 * *, p=38,24-0,52 \mathrm{p}^{<18}\right), 18(r=0,88 * *, p=40,27-$ $\left.-0,59 \mathrm{p}^{18}\right), 19 \cdot\left(\mathrm{x}=-0,76 * *, \mathrm{p}=41,42-0,42 \mathrm{p}^{19}\right)$. Não hou ve qualquer correlação entre o peso médio de 100 sementes e a porcentagem de sementes classificadas na peneira $20\left(r=0,25^{\mathrm{NS}}\right)$. Entretantó, a correlação foi significativa e positiva no caso de sementes classificadas nas peneiras $21(x=0,84 * *, p=24,76$ $\left.+0,43 \mathrm{p}^{21}\right), 22\left(r=0,73 * *, p=28,28+0,46 \mathrm{p}^{22}\right)$.

Esta alteração na distribujção do tamanho de sementes já havia sido observada por BIANCO (1978), com a di ferença de que o autor, utilizou uma distribuição de peneiras diferentes e, além disso, trabalhou com conjunto de peneiras e não com peneiras específicas. Assim, verificou correlações significativas e negativas entre o peso médio de 100 sementes e a porcentagem de sementes classificadas nas peneiras meno 
res de $19(r=-0,95 * *), 20-21(r=-0,90 * *)$ e $22-23\left(r=-0,64^{*}\right)$ e correlaçöes significativas e positivas com as porcentagens de sementes classificadas nas peneiras $24-25(r=0,76 *)$ e maiores que $26\left(r=0,84^{* *}\right)$. Deve-se observar que o autor, tambēm caliculou as porcentagens com relação ao peso de semen tes em diferentes peneiras.

E claro que, para um mesmo peso, ocorrerá um maior número de sementes pequenas do que sementes grandes. As sim os resultados ora observados seriam diferentes e mais in tensificados, se a avaliação da porcentagem de sementes de di ferentes diâmetros fosse feita em texmos de participação numé rica.

Finalmente, estudou-se os efeitos da competi. ção sobre os teores de nitrogênio, fósforo, potāssio, cálcio e magnēsio das sementes de amendoim. Os resultados estão apre sentados na Tabela 9. Utilizando-se os dados ora apresentados e os de peso da produção de sementes por planta, estudou-se as quantidades de cada elemento contidos em sementes por indivi duo de amendoim. Estes resultados estão apresentados na Tabe la 10.

Pode-se observar que o nitrogênio ćoi o elemen to encontrado em maior abundância nas sementes, seguido, em ordem decrescente, pelo potássio, fósforo, magnésio e, final mente, o cálcio. Esta ordem de grandeza está de acordo com as observadas por SICHMANN et ali (1970), DEUBER et ali (1978) e COELHO e TELLA (1967); embora os teores ora encontra dos sejam levemente inferiores aos obșervados pelos autores 


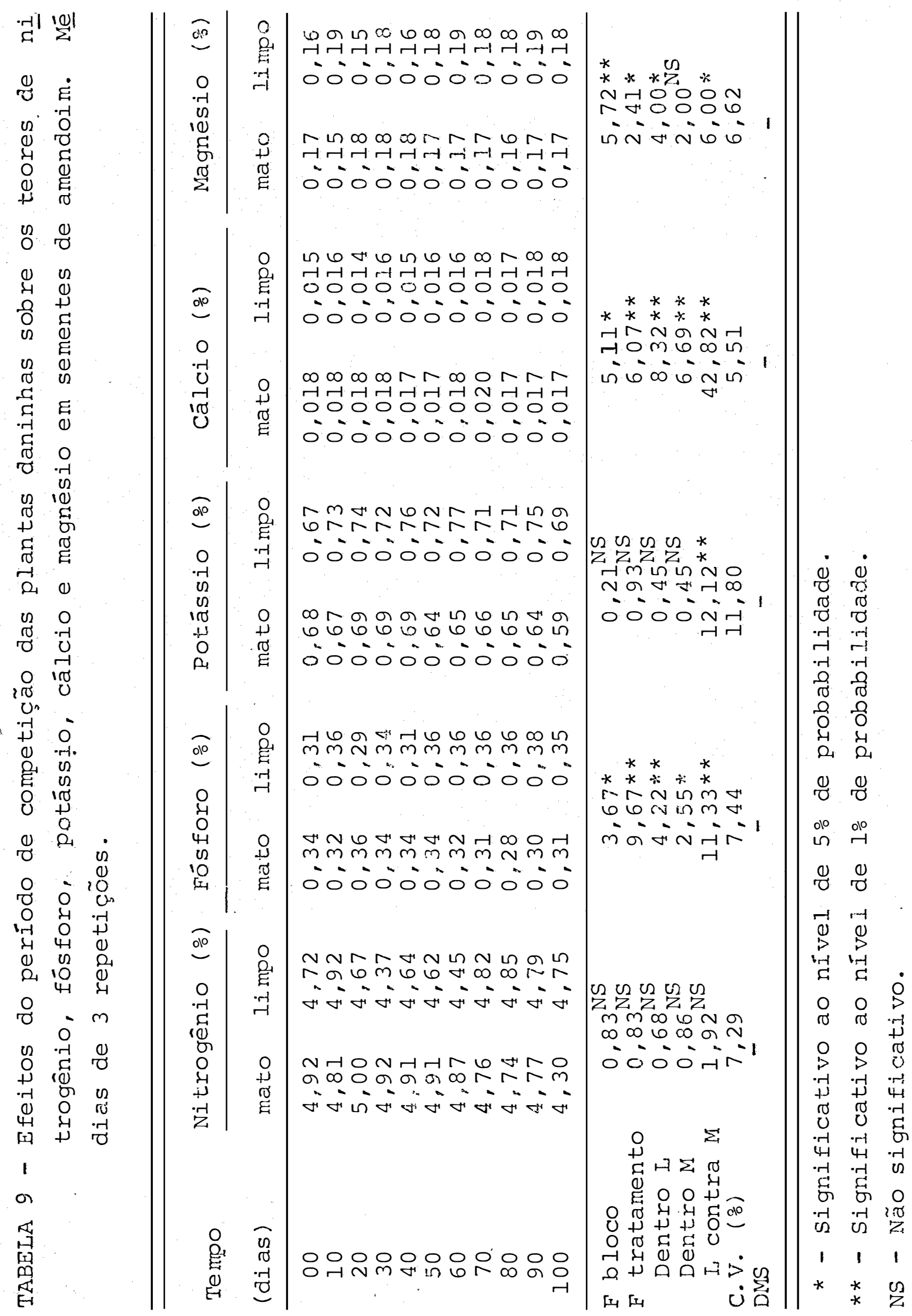




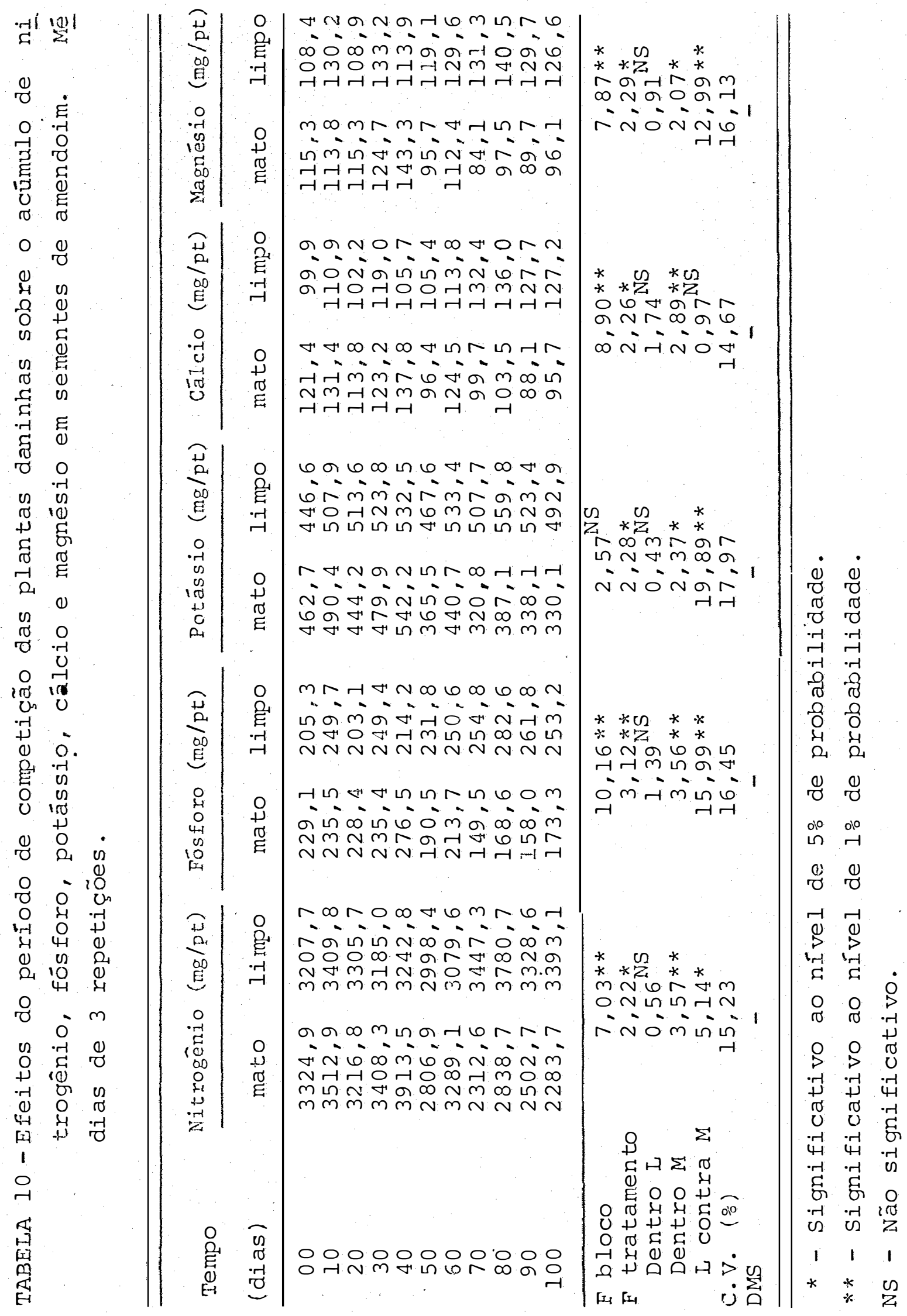


anteriores. Os resultados das anälises químicas do presente trabalho são baseados na matéria seca das sementes na integra, inclusive com óóleo. Como normalmente, antes da anälise quí mica de sementes de oleaginosas, primeiro extrae-se o óleo pa ra depois digerir a matéria seca da "torta", é possivel que os resultados sejam baseados neste material, possibilitando teores superiores dos elementos. Entretanto não há, nos tra balhos consultados, informações que nos permite comprovar a afirmação.

Não houveram efeitos significativos do período de competição sobre os teores de nitrogênio das sementes. En tretanto verificou-se correlação significativa e negativa en tre a extensão do período de competição, à partir da germina ção e os teores de nitrogênio das sementes de amendoim ( $r$ : $-0,71 *, n=5,01-0,004 t$, onde $\underline{N}$ é a porcentagem de nitrogê nio na matéria seca das sementes), indicando que aumentandose o tempo em que a cultura convivia com o mato, desde a ge minação, haverā uma tendência de decrēscimo dos teores deste elemento nas sementes. As plantas de amendoim desenvolvem as sociações mutualisticas com bactérias fixadoras de nitrogênio, o que as torna relativamente independentes do solo com relação à este elemento, explicando, em parte, os resultados obtidos no teste $\mathrm{F}$ e desdobramento dos graus de liberdader dos tratamen tos. Entretanto, as plantas daninhas podem não só interferir na instalação e desenvolvimento desta relação mutualistica coo mo também prejudicar o transporte deste elemento às sementes.

A quantidade de nitrogênio que cada. indivíduo 
acumulou nas sementes foi influenciado pela competição, prin cipalmente dentro do grupo de tratamentos com período inicial no mato, observando-se uma correlação altamente significativa deste parâmetro com o tempo no mato $\left(r=-0,75 * *, N_{s}=3637,1-\right.$. - 12,00 t, onde $\mathrm{N}_{\mathrm{S}}$ é a quantidade em $\mathrm{mg}$ de nitrogênio contido em sementes por plantas de amendoim). E claro que, esta va riação foi devịda quase que exclusivamente à própria massa de sementes por indivíduo.

Os teores de fósforo das sementes foram inflü enciados significativamente pela competição. Houveram con trastes significativos em ambos grupos de tratamentos e, tam bêm, foi significativa a comparação entre os grupos. $\AA$ seme lhança do ocorrido com o nitrogênio verificou-se correlação en tre o período no mato e os teores de fósforo nas sementes $(r=-0,72 *, p=0,35-0,0005 t)$. Além disso, verifi cou-se uma correlação significativa e positiva com a extensão do período inicial no limpo ( $r=0,62 *, p=0,32+0,0005$ t) indicando que quanto maior é o período em que a cultura é man tida no limpo; desde a germinação, maiores serão os teores de fósforo nas sementes.

Quando se estudou o acümulo de fósforo nas se mentes pode-se observar que os resultados referentes ao peso de sementes por planta foram determinantes neste tipo de parâ metro. Com efeito, houveram contrastes altamente significati vos nos teores de fósforo verificados no grupo de tratamentos com períodos iniciais no limpo, entretanto estes contrastes não foram significativos com relação ao acúmulo de fósforo em 
sementes, ressaltando o efeito moderador da influência da com petição neste grupo de tratamentos. No entanto, a tendência verificada nos teores ainda propiciou correlação significativa entre o acúmulo de fósforo nas sementes e extensão do período no limpo $\left(r=0,69 *, P_{S}=215,4+0,52 x\right.$, onde $\underline{P_{S}} e ́$ a quanti dade, em mg, de fōsforo contidas nas sementes de amendoim). A correlação entre extensão do período no mato também foi signi ficativa $\left(r=0,76 * *, P_{S}=250,9-0,91\right.$ t).

E importante ressaltar que pela primeira vez, dentre os parâmetros estudados no presente trabalho, verifi cou-se correlação significativa do parâmetro com a extensão do período no limpo. Os teores de fósforo do solo utilizado já são normalmente baixos e, além disso, de acordo com SICHMANN et atii (1970) 㐫 um elemento absorvido de maneira uniforme du rante todo o ciclo da cultura. Por isso, é possível que em qualquer período haja competição efetiva deste elemento que nunca seria bastante para suprir totalmente as duas partes en volvidas.

Não houve qualquex influência direta do tempo de competição sobre os teores de potássio nas sementes de amendoim. Apenas verificou-se significância no contraste que comparou os dois grupos de tratamentos. No grupo de tratamen tos com período iniciais no mato, os teores de potássio das sementes foram sensivelmente menores aos verificados no outro grupo de tratamentos. Houve uma tendência de influência da extensão do período inicial no mato sobre o teor de potássio nas sementes, acusada pela significância da correlação entre 
esses dois parâmetros $(r=-0,79 * *, K=0,69-0,0007 t$, onde $\underline{K}$ é o teor de potássio nas sementes, expresso em porcen tagem na materia seca). Neste mesmo grupo de tratamentos tam bém verificou-se correlação com o acümulo de $k$ nas. sementes : $r=$ $0,76 * *, K_{p}=503,0-1,69 t$, onde $K_{\mathrm{p}}$ é a quantidade de potäs sio, em mg, contidos em sementes de um individuo de amendoim). Neste parâmetro verificou-se contrastes significativos no gru po de tratamentos com período inicial no mato, evidenciando uma maior infliência do peso das sementes sobre a expressão deste parâmetro. De acordo, com SCHIMANN et azii (1970) e COELHO e TELLA (1967) o potássio é absorvido mais intensamente no coméço do ciclo de desenvolvimento do amendoim; sendo tal vez esta a possível explicação para os resultados verificados no desdobramento dos graus de liberdade do parâmetro de teor de potássio nas sementes.

Os teores de cálcio foram altamente influencia dos pela mato-competição em qualquer grupo de tratamentos e, também, quando se comparam os dois grupos de tratamentos. De acordo com COELHO e TELLA (1967), juntamente com o enxofre, é um elemento que tem seus teores incrementados com o desen volvimento da planta, ao contrário do que ocorre com os de mais macronutrientes, sendo olemento mais absorvido apōs o florescimento da cultura (SICHMANN et alii, 1970). O teor de cálcio na casca de amendoim tem sido utilizado como índice de nutrição dos frutos, tal é a influência que tem a disponi bilidade do cation no solo sobre os seus teores no fruto (COE LHO e TELLA, 1967). Segundo Bledsoe et alii (1949), citado 
por GEUS (1973), o amendoim absorve este elemento também pe los ginóforos ou frutos em formação. Isto talvez ocorra para compensar as suas necessidades, uma vez que o cálcio apresen ta baixa mobilidade na planta.

No presente trabalho, como não houve amontoa uma vez que nas parcelas no mato não seria possível, a aplica ção de gesso não foi tão eficiente devido a baixa solubilida de do produto. Isto explica os baixos teores de cálcio veri ficados nas sementes.

A presença inicial das plantas daninhas pode ter imobilizado grande parte do cálcio disponível não sendo possível a mineralização em tempo hábil para absorção pelo ginóforo ou fruto em formação. No caso do período inicial no limpo, durante à emissão do ginóforo; houve competição pelo cálcio, sendo que o cálcio se contactua com as regiões de ab sorção principalmente através do fluxo de massa (MALAVOLTA, 1979), as raizes apresentariam maior eficiência no recrutamen to deste elemento.

Verificou-se correlação significativa entre . o comprimento do período no limpo e o teor de cálcio nas semen tes $\left(r=0,83^{k}, \mathrm{Ca}=0,014+0,00003 t\right)$. Entretanto, esta correlação não foi significativa com relação ao período ini cial no mato, fornecendo umá possível indicação de que a com petição pelo cálcio exercida pelas plantas daninhas por oca sião ảe emissão do ginóforo e crescimento do fruto foi mais drástica que a imobilização inicial do elemento. Com efeito, os teores de cálcio nas sementes dos tratamentos com período 
inicial no mato foi significativamente superior aos teores ve rificados nas sementes do grupo de tratamentos com período ini cial no limpo, ao contrário do que aconteceu com os outros elementos.

Os resultados relativos ao acúmulo destes ele mentos nas sementes foram diferentes por motivos já expostos. Em ambọ os grupos de tratamentos houve correlação significa tiva deste parâmetro com o período de competição $(r=0,80 * *$, $\mathrm{Ca}_{\mathrm{S}}=100,9+0,31 \mathrm{t}$, no caso do período inicial no limpo e $r=0,72 * * \mathrm{Ca}_{\mathrm{S}}=130,2-0,36 \mathrm{t}$, no caso do período inicial no mato, onde $\mathrm{Ca}_{\mathrm{S}}$ é a quantidade de cálicio, em mg, contida em se mentes de amendoim por individuol.

Os teores de magnésio das sementes foram alte rados significativamente pela competição, embora não se tenha verificado corrèlação entre este parâmetro e a extensão do pe ríodo de competição em ambos os grupos de tratamentos, inclu sive no caso do acúmulo de magnésio nas sementes. Dentre os macronutrientes, com exceção do cálcio, o magnésio è o elemen to que se apresenta em menores teores nas sementes de amen doim, e não tendo ele a importância acima comentada com rela ção ao cálcio, é possível que a competição por este elemento não se instale com grande expressão. 
5. CONCLUSÕES

Para as condições de solo, clima, cultivar e tratos culturais em que foi desenvolvida a presente pesquisa, a competição, basicamente, alterou a distribuição porcentual do tamanho das sementes de amendoim aumentando a participação de sementes pequenas, classificadas com peneiras menores ou iguâis a 19, e, conseqüentemente, aumentando a participação de sementes grandes, iguais ou maiores a peneira 21. Com isso, o peso médio de 100 sementes foi reduzido significativamente. A participação de sementes classificadas na peneira 20 não foi alterada pela competição.

Além do peso médio de 100 sementes, o número de vagens por planta foi reduzido pela competição, sendo estes parãmetros responsáveis pelo decréscimo da produção de semen tes por planta, já que o número médio de sementes por vagem não foi influenciado.

o "stand" da cultura não sofreu influência sig nificativa das plantas daninhas e, portanto, a redução da prọ 
dução de sernentes por planta foi o fator determinante do de créscimo de produção de sementes por unidade de área. Esta última foi responsável pela redução da produção de vagens por unidade de área, uma vez que a porcentagem de casca não foi influenciada pela competição.

Os efeitos do mato foram mais intensos sobre os teores de cálcio, e fósforo das sementes, enquanto que o nitrogênio, potássio e magnésio foram apenas ligeiramente in fluenciados pela competição.

A manutenção da cultura livre da presença das plantas daninhas por um período de 10 dias a partir da germi nação proporcionou-lhe condições plenas de produtividade. No entanto, quando a cultura foi mantida no mato desde a germina ção foi necessário um periodo superior a 50 dias para que os diversos parâmetros produtivos da cultura do amendoim sofres sem 'influência significativa da competição. 
6. SUMMARY

With the objective of studying the effects of weed competition period over some productive parameters of Peanut crop cV. 'Tatū-53' was carried out the present research in Jaboticabal in a "Red Dark Latossol soil sandy phase".

The experimental design used was the "Randomi zed Block Design" being the treatments devided basically in two groups: in the first the crop was maintained in weed com petition since the germination up to a specific point of its development cycle and in the second one was conserved free of weed competition in equivalent periods to the first group, after the weeds were permitted to grow freely. The periods extensions studied were $0,10,20,30,40,50,60,70,80,90$ and 100 days.

Basically the weed competition altered the por centual distribution of seed size, increasing the participa tion of small seed sizes and, consequently, decreasing the pro portion of the big ones. In this way, the average weight of 
82.

100 seeds decreased. This fact and the decrease of pod num ber per plant were the main responsible for the decrease of seed production per plant, since the number of seeds per pod were not influenced.

The reduction of seed production per plant was the determinant factor of the decreasing of the pod producti vity, since neither the peanut stand nor the percentage of shell were not highly significant.

The weeds effects exerced a influence in the phosphorus and calcium content in peanut seeds, whereas, the nitrogen, potassium anda magnesium decresead slightly with the weed competition.

The peanut crop have show relatively tolerant to the weed competition, and a period of ten days of weed free in the begining of it development cycle proportionated fuli productivity when compared with the tratment maintened free of competition. In relation to the initial period in com petition the results, indicate that the period after the flo wering in general is critic, generally after the 50 days of the crop development cycle. 
83.

7. LITERATURA CITADA

ALOISI, R.R. e J.L.I. DEMATTÊ, 1974. Levantamento dos solos - da Faculdade de Medicina Veterinária e Agronomia de Jaboti cabal. Cientifica, Jaboticabal, 02:123-136.

BANTILAN, R.T.; M.C. PARADA e R.R. HARWOOD, 1974. Integrated Weed Management: 1. Key Factors Affecting Crop-Weed Balan ce. Philippine Weed Science Bulletin, (s.1.), 01:14.36.

BLEASDALE, J.K.A., 1960. Studies. on plant competition. In: HARPER, J.L. The Biology of Weeds. Oxford, Blackwell Sci entific Publication, p. 133-142.

BHAN, V.M.; M. SINCH e R.A. MAURYA, 1971. Crop weed Competị tion studies in Groundnuts. Indian Journal of Weed Scien $c e,(s .1), 03:. 32-36$.

BIANCO, S., 1978. Matocompetição em amendoim das "secas" sob diferentes condições de adubação. Jaboticabal, FCAV/UNESP, 66 p. (Trabalho de Građuação). 
BLANCO, H.G., 1972. A importância dos estudos ecológicos nos programas de controle das plantas daninhas. Biológico, são Paulo, $38: 343-350$.

BLANCO, H.G., 1978. Catálogo das espécies de mato infestantes de áreas cultivadas no Brasil. Campinas, CECORT/CATI, $\mathrm{s} / \mathrm{P}$

BUNTING, A.H. E J.D. LEA, 1957. The ecology and control of weeds at Tozi in East Central Sudan. Empt. Journal Experi mental Agricultural, 25:40-50.

CAMARGO, M., 1974. Diferentes doses de Treflan (trifluralin) e verificação de sua influência no poder germinativo da se mente de amendoim (Arachis hypogaea L.). Jaboticabal, FCAV/Uî̉eSP. 38 p. (Trabalho de Graduação) .

CLARKE, G.L., 1971. Elementos de Ecologia. Barcelona, Edi ciones Omega S.A., $534 \mathrm{p}$.

COELHO, F.A.S. e R. TELLA, 1967. "Absorção de nutrientes por plantas de amendoim na cultura de outono. Bragantia, Cam pinas, 26:233-252.

COMISSÃO DE SOLOS. Levantamento de reconhecimento dos solos do Estado de são Paulo e Rio de Janeiro. Rio de Janeiro, C.N.E.P.A./SNPA, 639 p. (Boletim 12).

DEUBER, R.A.; A. SAVY Fo e O.C. BATAGLIA, 1978. Efeito de herbicidas no desenvolvimento e na concentração de nutrien 
tes em amendoim (Arachis hypogaea L.). I. Herbicidas incor porados ao solo. Planta Daninha, Piracicaba, 01:19-24.

DRENNAN, D.S.H. e E.A. JENNINGS; 1977. Weed competition in irrigated cotton (Gossypium barbadense L.) and groundnut (Arachis hypogaea L.) in the Sudan Gezira. Weed Research, (s.1.), 17:03-09.

FEAKIN, S.D., Ed., 1973. Pest Control in Groundnuts. 3르 ed. London, Centre for Overseas Pest Research. $197 \mathrm{p}$.

FORSTER, R., 1968. Primeiros resulțados com herbicidas Ramrod (CP/31.393) para as culturas de milho e amendoim. In: VI Seminário Brasileiro de Herbicidas e Ervas Daninhas, Sete Lagoas, SBHED, p. 191-198.

FORSTER, R. e R. DEUBER, 1970. Herbicidas para aplicação a pré-plantio e após plantio para a cultura do amendoim. em solos Latossol e Podzólico. In: VIII Seminário Brasileiro de Herbicidas e Ervas Daninhas, Botucatu, SBHED, p. IX-05.

GRASSI, N. e L. LEIDERMAN, 1974. Estudos comparativos de her bicidas para amendoim. In: X Seminário Brasileiro de Her bicidas e Ervas Daninhas, Santa Maria, SBHED, p. 27.

GRASSI, N.; L. LEIDERMAN e K.V. HERTWIG, 1970. Aplicação de herbicidas em prē-emergência e pré-plantio em amendoim. In: VIII Seminário Brasilejro de Herbicidas e E̊rvas Daninhas, Botucatu, SBHED, p. IX-06. 
86.

GRASSI, N.; L. LEIDERMAN e K.V. HERTWIG, 1973. Controle quí mico das ervas daninhas em amendoim da seca. Biológico, São Paulo, 39: 158-161.

HAMDOUN, A.M., 1977. Competitive effects of weeds upon growth and yield of cotton, groundnuts and sorghum in the kenana area of the Sudan. Zeitschrift für Pflanzenkrankheiten und Pfianzenschutz, (s.1.), 84:509-515.

HAMMERTON, J.L., 1974 Weed control work in progress at the University of the West Indies. Part 4. PANS, (s.1.), 20: $429-436$

HAMMERTON, J.L., 1976. Problems of herbicide assessment in peanuts in Jamaica. Weed Research, (s.1.), 16:27-25.

HAUSER, E.W.; G.A. BUCHANAN e W.J. ETHREDGE, 1975. Competi tion of Florida beggarweed and Sicklepod with peanuts. I. Effects of periods of Weed-free maintenance or weed compe tition. Weed science, (s.1.), 23:368-372.

HAUSER, E.W. e S.A. PARHAM, 1969. Effects of annual weeds and cultivation on the yield of peanuts. Weed Research,(s.l.), Q99: $192-197$

HILL, L.V. e P.W. SANTERLMANN, 1969. Competitive effects of annual weeds on spanish peanuts. Weed Science, (s.1.), 17: $01-02$ 
HOI.M, L.G.; D.L. PLUCKNETT; J.V. PANCHO e J.P. HERBERGER, 1977. The World's Worst Weeds. Honolulu, University Press of Havaii, p. 609.

ISHAG, H.M., 1971. Weed control in irrigated groundnuts (Ara chis hypogaea L.) in the Sudan Gezira. Journal of AgricuI tural Sciences, Cambridge, 77:237-242.

LEIDERMAN, L.; R.J.C. PEREIRA e W. SICHMANN, 1963. Aplicações de herbicidas em pré-emergência no amendoim em terra areno sa. Bïológico. São Paulo, 29:61-65.

IEIDERMAN, L. e C.A.L. SANTOS, 1964. Aplicação de herbicidas de pré-emergência no amendoim em terra arenosa. Bio.lógi.co. São Paulo, 29:61-65:

LEIDERMAN, L. e C.A.L. SANTOS, 1966. Controle de gramíneas na cultura do amendoim com misturas de trifluralin e diuron em três regiões do Estado de são Paulo. In: VI Seminārio Bra sileiro de Herbicidas e Ervas Daninhas, Sete Lagoas, SBHED, p. $83-92$.

LEVI, R., 1975. Herbicidas em pré-plantio incorporados na cultura do amendoim. Jaboticabal, FCAV/UNESP. p. 43 (Tra balho de Graduação) .

OMETO, D.A., 1960. O cultivo químico em cultura do amendoim. In: III Seminário Brasileiro de Herbicidas e Ervas Dani nhas, Campinas, SBHED, p. 237-248. 
ORAM, P.A., 1961 Experiments on the control of weeds in groundnuts in Tripolitania. Weed Research, (s.1.), 01:211228 .

PACHECO, Rosilux P.B., 1977. Duração do período da competí ção de malerbas com a cultura do amendoim das āguas (Ara chis hypogaea L.). Ciência e Cultura, são Paulo, 29:559. (Suplemento)

RETHINAM, P.; G. SELVARANGARAJU; N. SANKARAN; S. SANKARAN e Y.B. MORACHAN, 1976. Studies on crop-Weed competition and chemical weed control in groundnut. Madras Agricultural Journal, (s.1.), 63:454-457.

RODRIGUEZ MARQUINA; E.L.; V. HEMSY; J. SCANDALIARIS; H.L. MU ÑOZ e J.A. CAJAZ, 1974. Período crítico de competência en tre las malezas y el cultivo del mani (Arachis hypogaea L.). Revista Agronomica del Noroeste Argentino, Tucuman, 11:137143 .

SADER, R., 1975. Controle químico de plantas daninhas na cul tura do amendoim (Arachis hipogaea L.). Piracicaba, ESALQ/ USP, p. 122 (Dissertação de Mestrado).

SANTOS, C.A.L.; L. LEIDERMAN e W. SICHMANN, 1977. Controle de ervas daninhas do amendoim "das águas" pela aplicação de herbicidas em pré-emergência e pré-plantio. Biológico, São Paulo, 33:244-256. 
SARRUGE, J.R. e H.P. HAAG, 1972. Anälises químicas em plan tas. Piracicaba, ESALQ, $1972.56 \mathrm{p}$. (mi meografado).

SCHILLER, J.M. : P. DOGKEAW E P. JINA, 1976. Weed control in rainfed peanut (Arachis hypogaea L.) production in Norther Thailand. Thai. Journal of Agricultural Science, $9: 51-65$.

SICHMANN, W.; A.M.L. NEPTUNE e N.P. SABINO, 1970. Acumulação de macronutrientes pelo amendoim (Arachis hypogaea L.) cuI tivado em outono na época da seca. Anais da Escola Supe rior de Agricultura "Luiz de Queiroz", Piracicaba, XXVII: $393-409$.

STEEL, R.G.D. e.J.H. TORRIE, 1960. Principles and procedures of statistics. New York, McGraw-Hill Book co., p. 481.

VICTORIA FILHO, R.; J.C. DURIGAN; R.A. PITELLI e J. NISHIMURA, 1976. Herbjcidas em pré-emergência e pré-plantio incorpo rado na cultura do amendoim (Arachis hypogaea L.). In: XI Seminário Brasileiro de Herbicidas e Ervas Daninhas, Lon drina, sBHED, p. 53 .

YORK, A.C. e H.D. COBLE, 1977. Panicum interference in pea nut. Weed Science, (s.1.), 25:43-47. 